\title{
Sulfate reduction and methane oxidation activity below the sulfate-methane transition zone in Alaskan-Beaufort continental margin sediments: Implications for deep sulfur cycling
}

Tina Treude ${ }^{a *}$, Stefan Krause ${ }^{a}$, Johanna Schweers ${ }^{a}$, Andrew W. Dale ${ }^{a}$, Richard Coffin ${ }^{b}$, Leila J. Hamdan ${ }^{b, c}$

${ }^{a}$ GEOMAR Helmholtz Centre for Ocean Research Kiel, Department of Marine Biogeochemistry, Wischhofstr. 1-3, 24148 Kiel, Germany

${ }^{b}$ US Naval Research Laboratory, Marine Biogeochemistry Section, 4555 Overlook Ave. SW, Washington, DC 20375, USA

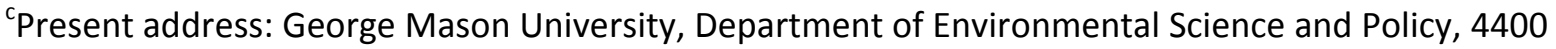
University Drive, Fairfax, VA 22030, USA

*Correspondence: ttreude@geomar.de

Key words: AOM, methanogenesis, iron, manganese, barite, inhibition, temperature

\begin{abstract}
Two 6 $\mathrm{m}$ long sediment cores were collected along the $\sim 300 \mathrm{~m}$ isobath on the Alaskan-Beaufort continental margin. Both cores showed distinct sulfate-methane transition zones (SMTZ) at 105 and 120 $\mathrm{cm}$ below seafloor (cmbsf). Sulfate was not completely depleted below the SMTZ but remained between 30 and $500 \mu \mathrm{M}$. Sulfate reduction and anaerobic oxidation of methane (AOM) determined by radiotracer incubations were active throughout the methanogenic zone. Although a mass balance could not explain the source of sulfate below the SMTZ, geochemical profiles and correlation network analyses of biotic and abiotic data suggest a cryptic sulfur cycle involving iron, manganese and barite. Inhibition experiments with molybdate and 2-bromoethanesulfonate (BES) indicated decoupling of sulfate reduction and $\mathrm{AOM}$ and competition between sulfate reducers and methanogens for substrates. While correlation network analyses predicted coupling of AOM to iron reduction, the addition of manganese or iron did not stimulate AOM. Since none of the classical archaeal anaerobic methanotrophs (ANME) were abundant, the involvement of unknown or unconventional phylotypes in AOM is conceivable. The resistance of AOM activity to inhibitors implies deviation from conventional enzymatic pathways. This work suggests the classical redox cascade of electron acceptor utilization based on Gibbs energy yields
\end{abstract}


does not always hold in diffusion-dominated systems, and instead biotic processes may be more strongly coupled to mineralogy. 


\section{INTRODUCTION}

Marine sediments on continental shelves and margins commonly feature a clear vertical separation between a sulfate-reducing and a methanogenic zone (Claypool and Kaplan, 1974). Sulfate-reducing bacteria have a high affinity to hydrogen (Kristjansson et al., 1982) and acetate (Schönheit et al., 1982), which maintain the concentrations of the substrates at levels too low for methanogens to prosper concomitantly. Consequently, methane does not accumulate in sediments before sulfate supply is nearly exhausted. Between these zones, where opposing fluxes of methane and sulfate meet, lies the zone of anaerobic oxidation of methane (AOM) (Knittel and Boetius, 2009). Here, sulfate and methane may be consumed simultaneously according to the equation (Barnes and Goldberg, 1976):

$\mathrm{CH}_{4}+\mathrm{SO}_{4}^{-} \rightarrow \mathrm{HS}^{-}+\mathrm{HCO}_{3}^{-}+\mathrm{H}_{2} \mathrm{O}$

This typically narrow zone of just a few centimeters, which features steep sulfate and methane gradients, is termed the sulfate-methane transition żone (SMTZ) (e.g., (Iversen and Jørgensen, 1985; Niewöhner et al., 1998; Treude et al., 2005a).

This general understanding of process organization based on the spatial decoupling of sulfate and methane has been revised by recent discoveries. For example, sediments in the Baltic Sea (Dale et al., 2008) and Black Sea (Knab et al., 2009) show a broad (1-2 m) SMTZ with extensive tailing of methane into the sulfate zone and inefficient methane consumption by AOM. The phenomenon in the Black Sea was interpreted to be the result of historic change between marine anoxic sediments and brackish oxidized clay caused by sea level rise and fall, respectively (Knab et al., 2009). Dale et al. (2008) argued that the interplay of thermodynamic and kinetic factors could also explain such tailing effects. In another study from the Baltic Sea, sulfate was not completely exhausted within the methanogenic zone, allowing sulfate reduction to penetrate below the conventional SMTZ (Holmkvist et al., 2011). A cryptic sulfur cycle including oxidation of downwardly diffusing sulfide with deeply buried iron was postulated to provide a sulfate source in these sediment layers. The source of iron was identified as iron-rich post-glacial sediment underlying Holocene marine mud. In both the Black Sea and the Baltic Sea studies, the presence (LeLoup et al., 2009; LeLoup et al., 2007) and activity (Holmkvist et al., 2011; Knab et al., 2009) of sulfate-reducing bacteria within the methanogenic zone has been confirmed. 
In recent years, our understanding of methane oxidation in sediments has been extended. In the traditional paradigm, microbial methane oxidation is accomplished by either aerobic methylotrophic bacteria with oxygen (Hanson and Hanson, 1996) or by a consortium of anaerobic methanotrophic (ANME) archaea and sulfate-reducing bacteria with sulfate as the terminal electron acceptor (Boetius et al., 2000; Orphan et al., 2001). However, different studies demonstrated that anaerobic methane consumption is more diverse with respect to electron acceptors, organisms, and syntrophic relationships than previously thought. Besides sulfate, also nitrate (Ettwig et al., 2010; Pernthaler et al., 2008) and iron/manganese (Beal et al., 2009; Wankel et al., 2012) can serve as electron acceptors for methane oxidation. In fresh water environments, where sulfate is minimally abundant, AOM with nitrate, performed by oxygenic bacteria instead of archaea, can be an important mechanism for methane removal (Ettwig et al., 2010). The syntrophic relationship between methanotrophic archaea and sulfate-reducing bacteria has been questioned in a recent study, which demonstrated that ANMEs are capable of reducing sulfate to elemental sulfur during AOM by an unknown pathway (Milucka et al., 2012). In this process, sulfate reducers, acting as sulfur fermenters, likely play a neutral commensal role rather than being an obligatory partner in AOM. Furthermore, studies indicate participation of non-sulfate reducing bacteria in AOM consortia, including members of the Betaprotobacteria (Pernthaler et al., 2008).

Here we present data from two sediment cores obtained from an east-west transect along the $\sim 300 \mathrm{~m}$ isobath on the Alaskan-Beaufort continental margin (Coffin et al., 2013), both showing sulfate reduction and AOM activity below the SMTZ (i.e. within the methanogenic zone). Sulfate was never completely exhausted below the SMTZ, but remained at values between 30 and 500 $\mu \mathrm{M}$. Our data suggest that the primary supply of sulfate could be provided by iron reactions according to the cryptic sulfur cycle proposed by Holmkvist et al. (2011); beyond that we suggest advanced sulfur re-cycling including reactions with manganese and barite. The mechanism of $\mathrm{AOM}$ and the relationship between $\mathrm{AOM}$, sulfate reduction, and methanogenesis below the SMTZ was studied using inhibition (molybdate, 2-bromoethanesulfonate) and addition (manganese, iron) experiments. 


\section{MATERIALS AND METHODS}

\subsection{Sediment coring, core description, and core sub-sampling}

Samples were collected on board the USCGC Polar Sea, on 25 September 2009 within a

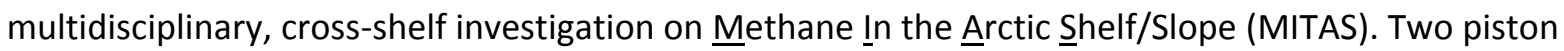
cores, PC13 ( $71^{\circ} 31.86300^{\prime} \mathrm{N}, 152^{\circ} 04.75420^{\prime} \mathrm{W}, 280 \mathrm{~m}$ water depth, core length $602 \mathrm{~cm}$ ) and PC12 $\left(71^{\circ} 32.97120^{\prime} \mathrm{N}, 152^{\circ} 03.68110^{\prime} \mathrm{W}, 342 \mathrm{~m}\right.$ water depth, core length $598 \mathrm{~cm}$ ) were collected north and east of Barrow Alaska, approximately $70 \mathrm{~km}$ north of Cape Halkett (Coffin et al., 2013). Detailed sedimentological and mineralogical analyses of PC13 and PC12 are published in Rose et al. (2012). In short, PC13 was primarily composed of $45-65 \%$ clay, $20-30 \%$ quartz, and 5- 15\% feldspar. Carbonates were present throughout the core in trace amounts. Calcite was identified at $354 \mathrm{cmbsf}$. Other possible trace minerals at $123 \mathrm{cmbsf}$ included pyrite. PC12 was dominated by the primary lithology (see PC13), except at the bottom of the core (594 cmbsf), where quartz and clay quantities decreased slightly and feldspar and trace minerals became more abundant. Dolomite was identified throughout the core and calcite was identified at $29 \mathrm{cmbsf}, 450 \mathrm{cmbsf}$, and $594 \mathrm{cmbsf}$. Other possible trace minerals in PC13 included pyrite, particularly at $231 \mathrm{cmbsf}$ and $594 \mathrm{cmbsf}$.

Piston cores (PC) (Coffin et al., 2013; Hamdan et al., 2013) were collected with a steel core barrel lined with $3 \times 300 \mathrm{~cm}$ long cellulose acetate butyrate liners with an inner diameter of $6.7 \mathrm{~cm}$. After retrieval, liners were removed from the core barrel, capped on each end, and sub-sampled (sediment and pore-water) at a resolution of $20-70 \mathrm{~cm}$ along the length of cores. Methane samples were obtained by drilling $2 \mathrm{~cm}$ holes into core liners and extracting $3 \mathrm{~mL}$ sediment plugs, which were immediately transferred into gas-tight 20-mL serum vials (Coffin et al., 2013). Each core was divided into $1 \mathrm{~m}$ sections and capped on each end. Sections were split horizontally using a core splitter (GEOTEK). The surface of the split core was scraped away and sterile polypropylene tubes were used to collect approximately $10 \mathrm{~g}$ of sediment for phylogenetic analysis from one half. Approximately $2 \mathrm{~g}$ of sediment from the same half was placed in pre-weighed snap tight petri dishes for porosity analysis. These were stored at $-80^{\circ} \mathrm{C}$ and $-20^{\circ} \mathrm{C}$, respectively, until analysis. For anaerobic oxidation of methane $(A O M)$ and sulfate reduction rate measurements, samples were taken with glass tubes ( 5 $\mathrm{mL}$ ) and sealed with butyl rubber stoppers at both ends according to Treude et al. (2005a). Two replicates per sampling depth as well as 13 ( $A O M$ ) and 5 (sulfate reduction) controls from various depths of PC12 and PC13 were taken. Sediment for in-vitro studies (methanogenesis, AOM, and sulfate reduction) was collected from several depths below the sulfate-methane transition zone 
(SMTZ) into sterile $100 \mathrm{~mL}$ glass vials without headspace. These were closed with butyl rubber stoppers and a screw cap and stored at $0^{\circ} \mathrm{C}$ in the dark until analysis. Approximately $2-25 \mathrm{~mL}$ of porewater was extracted with rhizons (Seeberg-Elverfeldt et al., 2005); Rhizosphere Research Products) from the second split half of the core. After insertion of the rhizon sampler into the split core, the dead volume inside of the rhizon, tubing and syringe were flushed with approximately $2 \mathrm{~mL}$ of sample porewater that was discarded through the side port on a three-way stopcock connected to the syringe.

\subsection{Porewater Analyses}

\subsubsection{Sulfate}

Sulfate $\left(\mathrm{SO}_{4}{ }^{2-}\right)$ samples were collected in $2 \mathrm{~mL}$ conical micro-centrifuge tubes with screw top caps containing a rubber gasket. Immediately prior to sample addition, a $0.8 \mathrm{M}$ solution of cadmium nitrate was added to each tube to prevent formation of $\mathrm{SO}_{4}{ }^{2-}$ from sulfide under oxic conditions. Subsequently, $1 \mathrm{~mL}$ of porewater was added to the tubes. Final concentration of cadmium nitrate was $0.04 \mathrm{M}$. Samples were held frozen $\left(-20^{\circ} \mathrm{C}\right)$ until analysis at the home laboratory (GEOMAR). Prior to analysis, samples were diluted (1:30) with $\mathrm{H}_{2} \mathrm{O} . \mathrm{SO}_{4}{ }^{2-}$ concentration was determined by ion exchange chromatography (761 IC-Compact, Metrohm). Analytical precision based on repeated analysis of IAPSO seawater standards (dilution series) was found to be $<1 \%$ with an absolute detection limit of $\sim 1 \mu \mathrm{M}$, corresponding to a detection limit of $\sim 30 \mu \mathrm{M}$ for the undiluted sample.

\subsubsection{Sulfide}

Total dissolved sulfides were determined shipboard according to Cline (1969) using a Turner spectrophotometer. Standard curves were generated using sodium sulfide (Sigma-Aldrich) solutions prepared in gas tight glass ampoules. The analytical precision calculated from repeated analysis of standards was $<10 \%$.

\subsubsection{Total alkalinity}

Total alkalinity (TA) in porewater was analyzed shipboard by direct titration in an open cell of $0.5 \mathrm{~mL}$ of porewater dispersed in $2 \mathrm{~mL}$ deionized water with $0.01 \mathrm{~N} \mathrm{HCl}$ using Bruevich's method (Ivanenkov and Lyakhin, 1978). Calibration was carried out with standard seawater (IAPSO). The titration method has a precision of $0.4 \%$. Concentrations were expressed as $\mathrm{mEq} \mathrm{L}^{-1}$.

\subsubsection{Dissolved inorganic carbon}


Dissolved inorganic carbon (DIC) concentration was determined shipboard with a UIC coulometer and quantified against certified reference seawater (Scripps Institute of Oceanography) (Coffin et al., 2013). Up to $5 \mathrm{~mL}$ of porewater was transferred to $10 \mathrm{~mL}$ glass serum vials (Wheaton) with Teflon lined septa sealed with aluminum crimp caps. Phosphoric acid (85\%) in a saturated $\mathrm{CuSO}_{4}$ solution was added to each vial to convert DIC to $\mathrm{CO}_{2}$ and to precipitate sulfide. $\mathrm{CO}_{2}$ was transferred to the coulometer with ultra high purity nitrogen gas. Precision based on repeated measurements of certified reference seawater was $2.4 \%$. For DIC stable carbon isotope ratio $\left(\delta^{13} \mathrm{C}\right)$ analysis, up to $2 \mathrm{~mL}$ of porewater was transferred to $3 \mathrm{~mL}$ glass serum vials (Wheaton) sealed with rubber lined aluminum crimp caps. Samples were held frozen $\left(-20^{\circ} \mathrm{C}\right)$ until analysis at the home laboratory. Immediately prior to analysis, phosphoric acid (85\%) was added to convert DIC to $\mathrm{CO}_{2}$. The samples were subsequently shaken, and a volume of headspace was transferred using a gas-tight glass syringe. Separation was achieved with a ThermoElectron trace gas chromatograph (GC) equipped with a Varian Porapak-Q column $\left(25 \mathrm{~m}, 0.32 \mathrm{~mm}\right.$ id). $\delta^{13} \mathrm{C}$-DIC was measured on a ThremoElectron Delta Plus XP Isotope Ratio Mass Spectrometer (IRMS). Stable isotope ratios were standardized using $\mathrm{CO}_{2}$ referenced to the NIST RM 8560 natural gas standard. Measured values were plotted against reported $\delta^{13} \mathrm{C}$ values to generate a normalization equation, which was applied to the Vienna Peedee Dee Belemnite (VPDB) scale. Data are expressed in the standard $\delta$-notation as \%o.

\subsubsection{Trace metals}

Porewater samples $(1 \mathrm{~mL})$ were added to acid-washed plastic vials and immediately acidified with 10 $\mu \mathrm{L} 36 \% \mathrm{HCl}$. Samples were stored refrigerated until analyses. Concentrations of $\mathrm{Fe}, \mathrm{Mn}, \mathrm{Mg}^{2+}, \mathrm{Ca}^{2+}$, and $\mathrm{Ba}^{2+}$ were determined in the home laboratory by Inductively Coupled Plasma Optical Emission Spectrometry (ICP-OES, JY 170 Ultrace, Jobin Yvon). Analytical precision based on repeated analysis of IAPSO seawater was found to be $<2 \%$ for $\mathrm{Mg}^{2+}$ and $\mathrm{Ca}^{2+}$ and $3-4 \%$ for $\mathrm{Fe}, \mathrm{Mn}$, and $\mathrm{Ba}^{2+}$.

\subsection{Methane}

Volumetric methane $\left(\mathrm{CH}_{4}\right)$ gas concentrations were determined using the headspace technique (Hoehler et al., 2000) and quantified against certified gas standards (Scott Gas). Concentration was calculated using sediment porosity and dry weight data. Analysis was performed shipboard using a Shimadzu 14-A gas chromatograph equipped with a flame ionization detector (FID) and Hayesep-Q $80 / 100$ column. Gases were separated isothermally at $50^{\circ} \mathrm{C}$. The analytical precision based on repeated analysis of gas standards was $0.4 \%$ (Coffin et al., 2013). $\mathrm{CH}_{4} \delta^{13} \mathrm{C}$ data were obtained from the same vials used for shipboard gas concentration analysis (see above). After gas analysis by FID, 
samples were inverted and stored frozen $\left(-20^{\circ} \mathrm{C}\right) . \delta^{13} \mathrm{C}-\mathrm{CH}_{4}$ was determined in the home laboratory using a trace gas chromatograph interfaced via a GC-C III combustion unit to a ThermoElectron Delta Plus XP Isotope Ratio Mass Spectrometer (Coffin et al., 2013). Measured values were plotted against reported $\delta^{13} \mathrm{C}$ values to generate a normalization equation. Data were referenced to VPDB and are expressed in the standard $\delta$-notation as \%o.

\subsection{Porosity and density}

Sediment porosity was measured gravimetrically in the home laboratory as described by (Hoehler et al., 2000). Frozen samples were thawed, equilibrated to room temperature, weighed, and dried at $60^{\circ} \mathrm{C}$ overnight, then re-weighed to determine sediment water content. Water content was determined assuming a water and dry sediment density of 1.035 and $2.500 \mathrm{~g} \mathrm{~cm}^{-3}$, respectively. Porosity together with water and dry sediment density were used to calculate wet sediment density.

\subsection{Anaerobic oxidation of methane, ex situ}

${ }^{14} \mathrm{C}_{-} \mathrm{CH}_{4}$ dissolved in seawater (injection volume $30 \mu \mathrm{L}$, activity $5 \mathrm{kBq}$, specific activity $2.28 \mathrm{GBq} \mathrm{mmol}^{-}$ $\left.{ }^{1}\right)$ was injected into each sample. Samples were incubated shipboard at in-situ temperature $\left(0.5^{\circ} \mathrm{C}\right)$ for $16 \mathrm{hrs}$ in the dark. To terminate bacterial activity, samples were transferred to $40 \mathrm{~mL}$ glass vials filled with $20 \mathrm{~mL}$ sodium hydroxide $(2.5 \% \mathrm{w} / \mathrm{w})$ and closed immediately with rubber stoppers. The vials were shaken to equilibrate porewater $\mathrm{CH}_{4}$ between aqueous and gaseous phase. Controls were terminated with sodium hydroxide before addition of tracer. In the home laboratory, AOM rates were determined according to (Treude et al., 2005b) (gas chromatography, ${ }^{14} \mathrm{C}_{-} \mathrm{CH}_{4}$ combustion, and calculation) and (Joye et al., 2004) $\left({ }^{14} \mathrm{C}-\mathrm{CO}_{2}\right.$ trapping). Samples were regarded active only if: sample value $>$ control mean $+(3 \times$ standard deviation $)$. If a sample value passed this threshold, the control mean was subtracted from the sample value.

\subsection{Sulfate reduction, ex situ}

Sampling, injection and incubation procedures were similar as for AOM. To each sample, $12 \mu \mathrm{L}$ of carrier-free ${ }^{35} \mathrm{~S}_{-} \mathrm{SO}_{4}{ }^{2-}$ (activity $400 \mathrm{kBq}$, specific activity $37 \mathrm{TBq} \mathrm{mmol}^{-1}$ ) was injected. To terminate bacterial activity, samples were transferred to $50 \mathrm{~mL}$ plastic centrifuge tubes containing $20 \mathrm{~mL}$ of zinc acetate $(20 \% \mathrm{w} / \mathrm{w})$. Controls were terminated with zinc acetate before tracer addition. Rates were determined using the cold-chromium-distillation method (Kallmeyer et al., 2004). Samples were regarded active only if: sample value $>$ control mean $+(3 x$ standard deviation). If a sample value passed this threshold, the control mean was subtracted from the sample value. 


\subsection{Methane production, in vitro}

Sediments for in-vitro studies from PC12 (357, 418, $513 \mathrm{~cm}$ below seafloor (cmbsf)) and PC13 (329, $417 \mathrm{cmbsf}$ ) within the methanogenic zone (see Fig. 1 and 2) were used to determine potential rates of $\mathrm{CH}_{4}$ production. Experiments were started 6 months after sample collection. First, stock slurries of 1:1 mixtures of sediment and artificial seawater medium (Widdel and Bak, 1992) with a sulfate concentration of $0.5 \mathrm{mM}$ were prepared from the original sediment in sterile screw-neck bottles (Schott, Mainz) under an $\mathrm{N}_{2}$-atmosphere. Subsequently, $3 \mathrm{ml}$ of stock slurry and $6 \mathrm{~mL}$ of medium were transferred into $15 \mathrm{~mL}$-Hungate tubes (Dunn, Asbach; final sediment dilution 1:6). The tubes were closed with butyl rubber stoppers and incubated in a $\mathrm{N}_{2} / \mathrm{CO}_{2}$ headspace (gas mixture $(80 / 20$ $\mathrm{v} / \mathrm{v})$ ) at in-situ temperature $\left(0.5^{\circ} \mathrm{C}\right)$ for 35 days. Headspace samples $(0.1 \mathrm{ml})$ were taken repeatedly with gas tight syringes and analyzed for $\mathrm{CH}_{4}$ using a Hewlett Packard-5890 gas chromatograph equipped with a flame ionization detector and a Poropak-Q 80/100 column. Gases were separated isothermally at $75^{\circ} \mathrm{C}$ with helium carrier gas. $\mathrm{CH}_{4}$ production rates were derived from the linear increase in $\mathrm{CH}_{4}$ content in the headspace of each replicate over time. Data are presented per volume undiluted sediment after conversion with the dilution factor.

\subsection{Inhibition of sulfate reduction with molybdate, in vitro}

Inhibition experiments with molybdate $(22 \mathrm{mM})$ were carried out to examine characteristics of sulfate reduction and its potential coupling to AOM within the methanogenic zone of PC12 and PC13. Molybdate is an analogue to $\mathrm{SO}_{4}{ }^{2-}$, which inhibits sulfate reduction competitively (Oremland and Capone, 1988). We used combined sediment slurries from the methane production experiment (see 2.7) after termination of the incubation to ensure presence of methanogenic activity. Two sets of sediment slurries, with and without $22 \mathrm{mM}$ molybdate, were prepared for each depth and core (see 2.7) under an $\mathrm{N}_{2}$ atmosphere using artificial seawater medium (Widdel and $\mathrm{Bak}, 1992$ ), $\mathrm{SO}_{4}{ }^{2-}$ concentration $0.5 \mathrm{mM}$ ), achieving a final sediment dilution of 1:10. The dilution was higher compared to the method described in section 2.7, due to limited sediment quantities. Subsequently, six subsamples were prepared from each set of slurries: $5 \mathrm{~mL}$ Hungate tubes were filled bubble free with slurry and closed gas tight with butyl rubber stoppers. This transfer was done under an $\mathrm{N}_{2}$ or $\mathrm{CH}_{4}$ atmosphere (final $\mathrm{CH}_{4}$ concentration $\sim 1.48 \mathrm{mM}$; (Yamamoto et al., 1976) and in triplicate for the determination of either methane-independent sulfate reduction or AOM rates, respectively. Finally, $6 \mu \mathrm{L}$ carrier free ${ }^{35} \mathrm{~S}^{-\mathrm{SO}_{4}}{ }^{2-}$ radiotracer (activity $200 \mathrm{kBq}$, specific activity $37 \mathrm{TBq} \mathrm{mmol}^{-1}$ ) was injected into sulfate reduction vials and $15 \mu \mathrm{L}{ }^{14} \mathrm{C}-\mathrm{CH}_{4}$ radiotracer (activity $2 \mathrm{kBq}$, specific activity $2.28 \mathrm{GBq}$ 
$\mathrm{mmol}^{-1}$ ) into AOM vials. All vials were incubated for 3 days in the dark at $13^{\circ} \mathrm{C}$. Details of the incubation setup are provided in Table 1. After experiment termination, sulfate reduction and AOM samples were treated and analyzed according to section 2.6 and 2.5, respectively. All rates were presented per volume of undiluted sediment after conversion with the dilution factor. Student's ttest was applied (independent, two-tailed, $\alpha=0.05$ ) to detect significant differences between mean rates with and without molybdate.

2.9 Inhibition of AOM and methanogenesis with 2-bromoethanesulfonate (BES), in vitro

Inhibition experiments with 2-bromoethanesulfonic acid (BES, 60 mM; Hoehler et al., 1994), were carried out to examine characteristics of $A O M$ and its coupling to sulfate reduction within the methanogenic zone of PC13 and PC12. BES is an analogue of coenzyme-M (Gunsalus et al., 1978) in methanogenic archaea, which blocks $\mathrm{CH}_{4}$ formation as well as reverse methanogenesis (AOM). BES was added to a final concentration of $60 \mathrm{mM}$ (Hoehler et al., 1994). Experimental setups, analyses, and calculations were identical to as described in section 2.8 .

2.10 Addition of manganese and iron, in vitro

The potential coupling of AOM to manganese and iron reduction (Beal et al., 2009) below the SMTZ was investigated in combined sediment slurries retrieved from the methane production experiments (2.7). Radiotracer techniques for AOM and sulfate reduction rates described in section 2.8 were applied. Slurries (1:10 final sediment dilution) were prepared with artificial seawater medium (Widdel and Bak, 1992), sulfate concentration $0.5 \mathrm{mM}$ ) under an $\mathrm{N}_{2}$ atmosphere achieving a final sediment dilution of 1:10 (see 2.8). Reducible iron and manganese were added separately in the forms of ferric oxyhydroxide (Lovley and Phillips, 1986) and Na-birnessite (Feng et al., 2000), respectively. Before incubations, minerals were sterilized with $70 \%$ ethanol for 30 minutes, washed with filter sterilized (Whatman $0.2 \mu \mathrm{m}$ ) ultra-purified water, and air-dried at $20^{\circ} \mathrm{C}$. The final concentration of ferric oxyhydroxide and Na-birnessite in sediment slurries was $10 \mathrm{mM}$. To inhibit either sulfate reduction or AOM/methanogenesis, $22 \mathrm{mM}$ molybdate (see 2.8) and $60 \mathrm{mM} 2$ bromoethanesulphonate (BES, see 2.9), respectively, were added to replicates. Slurries without the addition of iron or manganese served as "background" controls. Each approach was done in triplicate in the dark at $13^{\circ} \mathrm{C}$. Preparation of Hungate tubes, injection of radiotracers, and analyses of $A O M$ and sulfate reduction samples was identical to 2.8 , except that all incubations were conducted with $\mathrm{CH}_{4^{-}}$ saturated slurries. "Medium" controls (5 each for background, +molybdate, +BES) were first 
terminated before addition of radiotracers. For an overview of incubation setups and replicates/controls see Table 2 .

To test whether mean AOM and sulfate reduction rates differed between experimental treatments, one-way Analysis of Variance (ANOVA) with a significance level of 5\% was applied. Tukey's post-Hoctest was used to identify mean values that differed significantly $(p=0.05)$. For each depth, means of the three inhibitor-free treatments as well as all means of all nine treatments were compared.

\subsection{Molecular biology}

Genomic DNA was extracted from sediment using the FastDNA ${ }^{\circledR}$ SPIN kit for soil (MP Biomedicals Inc.). Approximately $10 \mathrm{ng}$ of DNA was used as polymerase chain reaction (PCR) template. Samples were analyzed first by Length Heterogeneity-PCR (LH-PCR) as a quality control for linear amplification and to normalize PCR yield before pooling (Hamdan et al., 2013). Hypervariable regions V1 and V2 of the small subunit rRNA were amplified using the primers 6-FAM-27F and 355R for bacteria and $1 \mathrm{HK}$ and 589R for archaea (Hamdan et al., 2013). Positive (E. coli and S. solfataricus) and negative controls (diethylpyrocarbonate-treated water) were measured alongside. The PCR mixture and run conditions are described elsewhere (Hamdan et al., 2013; Hamdan et al., 2011). The product was quantified on an agarose gel with ethidium bromide, diluted, mixed with ILS-600 (Promega) and HiDi formamide, and analyzed on an ABI3130.

Multitag Pyrosequencing (MTPS) was performed using barcoded forward bacterial and archaeal primers (27F and $1 \mathrm{HKF}$ respectively), the emulsion PCR-A titanium adapter, reverse fusion primers (355R and 589R) and the emulsion PCR-B titanium adapter as described in detail in (Hamdan et al., 2013). The amplified product was quantified, diluted for normalization and pooled. The pooled product was quantified by the Quant-iT PicoGreen assay (Invitrogen) on a Beckman Coulter DTX 880 and diluted for 454 emulsion PCR. Sequencing was performed on the Roche GS-FLX Jr. Data were analyzed by the GS run browser with signal processing for shotgun or paired end and processed in the QIIME pipeline (qiime.sourceforge.net). Sequences $<200 \mathrm{bp}$ long, with quality scores $<25$, with multiple Ns and chimeras were excluded. Operational taxonomic units (OTUs) were clustered with CD-HIT at 97\% similarity. Sequences were aligned with PyNAST against the Greengenes core set and phylogeny was assigned with RDP. BLAST searches against GenBank were also performed to provide information on OTUs not classified by RDP.

\subsection{Correlation network model}


To explore direct and indirect interactions between microorganisms and abiotic parameters from PC13, correlation distance network analysis was employed. This approach has been used in numerous recent investigations to (a) provide information on covariance patterns between biotic and abiotic variables, (b) better describe the manner in which organisms are interacting with their local environment, and (c) understand how the local environment shapes these communities (Barberan et al., 2012; Gilbert et al., 2012; Steele et al., 2011). To create these networks, data on (a) the relative abundance of OTUs in each sample, (b) porewater and sediment geochemistry, and (c) $\mathrm{AOM}$ and sulfate reduction rates were analyzed using the Spearman's correlation function in a custom R module operated on George Mason University Microbiome Analysis Center's Galaxy Portal (http://mbac.gmu.edu). The Spearman's correlation is a nonparametric measure of statistical dependence between two variables. The analysis results in a correlation matrix describing the nature of the relationship (positive or negative) and statistical dependence ( $\rho=+1$ to -1 ) of paired variables. The correlation matrix data file was filtered for correlations with a Spearman's coefficient ( $\rho$ ) greater than 0.4 that were statistically significant $(p<0.05)$. The correlation matrix was imported into Cytoscape (v. 2.8; http://www.cytoscape.org), an open source software program for visualizing interactions, as a network so that the correlations could be mapped. Each variable in the network appears as a discrete node (a position on the map). Any correlations between variables (nodes) are indicated as edges (lines connecting variables), and the nature of the correlation (positive or negative) between variables (nodes) was identified by edge color (green = negative; purple = positive). Because the approach incorporates the totality of data in a correlation matrix, and summarily depicts all of the interactions of any single variable with all other variables, it is an ideal means to explore the complex relationships between sediment microorganisms and the biogeochemical environment.

\subsection{Calculation of solute fluxes derived from porewater concentrations}

To assess the potential coupling of iron oxyhydroxide reduction by $\mathrm{H}_{2} \mathrm{~S}$ to sulfate reduction and AOM (Table 3), fluxes of dissolved and solid phases were calculated. As a point of reference, fluxes were determined at the depth of SMTZ, defined as the depth where the linear $\mathrm{SO}_{4}{ }^{2-}$ and $\mathrm{CH}_{4}$ concentration gradients overlap. This depth was estimated at $105 \mathrm{~cm}$ for PC13 and $120 \mathrm{~cm}$ for PC12 (see Results).

Diffusive fluxes $\left(\mathrm{J}, \mathrm{mmol} \mathrm{cm}{ }^{-2} \mathrm{yr}^{-1}\right)$ of solutes $\left(\mathrm{C}, \mathrm{mmol} \mathrm{cm}^{-3}\right)$ into or out of the SMTZ were calculated using Fick's first law: 
$J=-\varphi D_{S} \frac{\partial C}{\partial z}$

where $\varphi\left(\mathrm{cm}^{3}\right.$ porewater $\left.\left(\mathrm{cm}^{3} \text { wet sediment }\right)^{-1}\right)$ is sediment porosity at the SMTZ, $D_{S}\left(\mathrm{~cm}^{2} \mathrm{yr}^{-1}\right)$ is the bulk sediment diffusion coefficient and $\partial C / \partial z$ is the concentration gradient of the linear part of the concentration profile above or below the SMTZ. $D_{S}$ values were calculated from free diffusion coefficients in seawater $\left(D_{s w} \mathrm{~cm}^{2} \mathrm{yr}^{-1}\right)$ by correcting for the sediment tortuosity (Boudreau, 1997):

$D_{S}=\frac{D_{S W}}{1-\ln \left(\varphi^{2}\right)}$

Porosity decreased only gradually with depth in both cores, being 0.67 $\pm 0.02(1 \sigma)$ at PC12 and $0.66 \pm 0.02$ at PC13 $(1 \sigma)$ and these values were used in the calculations.

Bulk sediment accumulation rates $\left(F_{\text {sed }}, \mathrm{g} \mathrm{cm}^{-2} \mathrm{yr}^{-1}\right)$ were calculated as:

$F_{\text {sed }}=\rho \omega(1-\varphi)$

where $\rho\left(\mathrm{g} \mathrm{cm}^{-3}\right)$ is the density of dry sediment and $\omega\left(\mathrm{cm} \mathrm{yr}^{-1}\right)$ is the bulk sediment burial velocity. The latter was calculated from the mean linear burial velocity reported for core JPC8 (Darby et al., 2009) sampled close to PC13. This value is based on numerous ${ }^{14} \mathrm{C}$ analyses on shell fragments sampled at depths between 51 and $1153 \mathrm{~cm}$ throughout that core. No information is available for the burial velocity in PC12, and so we assume the same value for this site. Uncertainty in the burial velocity has a minor impact on our calculated importance of reactive iron to AOM rates (see later section). Fluxes of individual elements due to sediment burial were calculated by multiplying $F_{\text {sed }}$ by the corresponding elemental content.

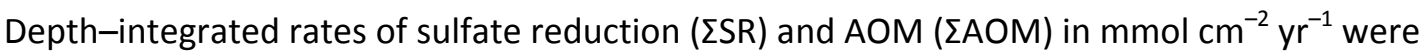
calculated from the SMTZ down to the bottom of the core by trapezoid integration considering the measured rate and porosity at each depth.

The sum of $A O M$ and methanogenesis reactions is stoichiometrically equivalent to sulfate reduction (Table 3). The ratio of the upward diffusive flux of DIC and downward diffusive flux of $\mathrm{SO}_{4}{ }^{2-}$ above the SMTZ was therefore used to estimate the number of moles of DIC produced per mole of $\mathrm{SO}_{4}{ }^{2-}$ reduced during sulfate reduction, $r_{c: s}$ (Table 3 ). The DIC flux was corrected for carbonate precipitation using the diffusive flux of $\mathrm{Ca}^{2+}$, above the SMTZ. For PC13, $\mathrm{Ca}^{2+}$ data were insufficiently resolved over depth to determine the flux, and the $\mathrm{Ca}^{2+}$ flux at PC12 was used as an approximation. 
Following (Burdige and Komada, 2011), $r_{c: s}$ was then used to calculate the oxidation state of carbon being mineralized in the sediment, ox:

$o x=4-8 / r_{c: S}$

The inferred value of $o x$ enables the reaction stoichiometry of methanogenesis to be derived (Table $3)$. 


\section{RESULTS}

\subsection{Geochemical parameters and ex situ turnover rates}

\subsubsection{PC13, $280 \mathrm{~m}$ water depth}

Geochemical parameters and ex situ turnover rates in $\mathrm{PC} 13$ are shown in Fig. 1. $\mathrm{SO}_{4}{ }^{2-}$ concentrations linearly decreased from the top of the core $(15 \mathrm{cmbsf}, 26.7 \mathrm{mM})$ to $110 \mathrm{cmbsf}(0.138 \mathrm{mM})$. Below this depth, $\mathrm{SO}_{4}{ }^{2-}$ remained low $(0.034-0.456 \mathrm{mM})$ but never reached the detection limit. $\mathrm{CH}_{4}$ concentrations were high (10.4-14.2 mM) between 260 and 551cmbsf, marking the methanogenic zone. Since concentrations in the methanogenic zone were above atmospheric saturation levels (Yamamoto et al., 1976), we cannot exclude that degassing occurred during core recovery leading to an underestimation of in situ concentrations. Above $260 \mathrm{cmbsf}, \mathrm{CH}_{4}$ steadily decreased reaching values $<0.03 \mathrm{mM}$ at $70 \mathrm{~cm}$. The sulfate-methane transition zone (SMTZ) was located at approximately $105 \mathrm{cmbsf}$ (Table 4). Sulfate reduction rates were elevated at the shallowest measured depth ( $34 \mathrm{cmbsf}, 0.54 \mathrm{nmol} \mathrm{cm}^{-3} \mathrm{~d}^{-1}$ ) and peaked below the SMTZ between 173 and 268 cmbsf (max. $1.73 \mathrm{nmol} \mathrm{cm}^{-3} \mathrm{~d}^{-1}$ ). Below the SMTZ, sulfate reduction was still detectable at rates between 0.04 and $0.45 \mathrm{nmol} \mathrm{cm}^{-3} \mathrm{~d}^{-1}$ until the bottom of the core $(571 \mathrm{cmbsf})$. AOM rates were low above the SMTZ ( $\leq 0.05 \mathrm{nmol} \mathrm{cm}{ }^{-3} \mathrm{~d}^{-1}$ until $83 \mathrm{cmbsf}$ ) and increased considerably below the SMTZ to the base of the core $\left(0.24-2.40 \mathrm{nmol} \mathrm{cm}^{-3} \mathrm{~d}^{-1}\right)$. Total sulfide concentration showed considerable scatter throughout the core. The highest sulfide concentration $(27 \mu \mathrm{M})$ was measured at the SMTZ; several secondary peaks between 7.3 and $11 \mu \mathrm{M}$, interrupted by zero values, were detected deeper in the core. We cannot exclude underestimation of sulfide concentrations due to potential concomitant degassing of sulfide with methane (see above). Dissolved inorganic carbon (DIC) and total alkalinity (TA) had nearly identical profiles, demonstrating that TA was dictated by DIC with little contribution from sulfide. Both parameters increased sharply between 15 and $110 \mathrm{cmbsf}$, and more gradually between $110 \mathrm{cmbsf}$ to the bottom of the core. Maximum DIC concentration was detected at $546 \mathrm{cmbsf}(79.4 \mathrm{mM})$ while TA peaked at $526 \mathrm{~cm}\left(69.8 \mathrm{mEq} \mathrm{L}{ }^{-1}\right) . \delta^{13} \mathrm{C}^{-} \mathrm{CH}_{4}$ decreased from the top of the core (-48.2\%) to a minimum of $-100 \%$ at $130 \mathrm{cmbsf}$. Below $130 \mathrm{cmbsf}$, values steadily increased, with a change in steepness at $240 \mathrm{cmbsf}$ reaching $-83.6 \%$ at the bottom of the core. $\delta^{13} \mathrm{C}$-DIC decreased from the top of the core $(-3.40 \%$ ) to a minimum of $-21.5 \%$ at $87.5 \mathrm{cmbsf}$. Below this minimum, values steadily increased, with a change in steepness at approximately 150 cmbsf reaching $4.69 \%$ at the bottom of the core. Concentrations profiles of $\mathrm{Fe}, \mathrm{Mn} \mathrm{Ba}^{2+}, \mathrm{Ca}^{2+}$, and $\mathrm{Mg}^{2+}$ were incomplete due to limited porewater volume; therefore partial profiles of upper (15-50 cmbsf) and lower (321-506 cmbsf) core sections are reported. Porewater Fe and $\mathrm{Mn}$ were detected 
in both sections and highest concentrations were observed in the lower section (max. 82.6 and 9.80 $\mu \mathrm{M}$, respectively). $\mathrm{Ba}^{2+}$ concentration was considerably lower in the upper compared to the lower section. $\mathrm{Ca}^{2+}$ ranged between 6 and $10 \mathrm{mM}$ in both sections. $\mathrm{Mg}^{2+}$ was lowest in the upper (49.4 mM) and highest in the lower section (55.5 mM).

\subsubsection{PC12, $342 \mathrm{~m}$ water depth}

Geochemical parameters and ex situ turnover rates of $\mathrm{PC} 12$ are shown in Fig. 2. $\mathrm{SO}_{4}{ }^{2-}$ concentrations in PC12 remained high in the upper $50 \mathrm{cmbsf}$ (between 27 and $25 \mathrm{mM}$ ) and linearly decreased below, reaching $2.5 \mathrm{mM}$ at $130 \mathrm{mbsf}$. Between 130 and $345 \mathrm{cmbsf} \mathrm{SO}_{4}{ }^{2-}$ fluctuated between 0.1 and $1.2 \mathrm{mM}$ but generally decreased with depth. Below $345 \mathrm{cmbsf}, \mathrm{SO}_{4}{ }^{2-}$ concentrations decreased below $0.1 \mathrm{mM}$ but never reached zero. $\mathrm{CH}_{4}$ concentrations were highest between 220 and $585 \mathrm{cmbsf}$ with values fluctuating between 8.9 and $12.6 \mathrm{mM}$. As these concentrations were above atmospheric saturation, they may underestimate in situ concentrations (see 3.1.1). $\mathrm{CH}_{4}$ linearly increased from 0.2 to $12.2 \mathrm{mM}$ between 130 and $280 \mathrm{cmbsf}$. Above $130 \mathrm{cmbsf}$, concentrations were low reaching a minimum (0.006 mM) at $50 \mathrm{cmbsf}$. The SMTZ was located at approximately $120 \mathrm{cmbsf}$ (Table 4). Sulfate reduction rates were highest at the shallowest measured depth $\left(38.4 \mathrm{nmol} \mathrm{cm}^{-3} \mathrm{~d}^{-1}\right)$, and decreased to $<1 \mathrm{nmol} \mathrm{cm} \mathrm{d}^{-1}$ at $86 \mathrm{cmbsf}$. From approximately the SMTZ depth to $319 \mathrm{cmbsf}$ sulfate reduction rates fluctuated between 0.02 and $16.9 \mathrm{nmol} \mathrm{cm}^{-3} \mathrm{~d}^{-1}$. Below $319 \mathrm{cmbsf}$, rates decreased to $<2.0 \mathrm{nmol} \mathrm{cm}^{-3} \mathrm{~d}^{-1}$. AOM was relatively low (average $<0.23 \mathrm{nmol} \mathrm{cm}^{-3} \mathrm{~d}^{-1}$ ) above the SMTZ compared to below where AOM rates fluctuated between 0.56 and $4.25 \mathrm{nmol} \mathrm{cm}^{-3} \mathrm{~d}^{-1}$. A peak in AOM of $\sim 8 \mathrm{nmol} \mathrm{cm}^{-3} \mathrm{~d}^{-1}$ was detected at $319 \mathrm{mbsf}$. Total sulfide was detected at $87.5 \mathrm{cmbsf}$ (3.7 $\mu \mathrm{M})$ immediately above the SMTZ, reached maxima of $11-14 \mu \mathrm{M}$ between 220 and $325 \mathrm{cmbsf}$, and was undetectable at depths below $405 \mathrm{cmbsf}$ with the exemption of $485 \mathrm{cmbsf}$. As mentioned above (3.1.1), sulfide concentrations may be underestimated due to concomitant degassing with methane. Similar to PC13, DIC and TA had analogous concentration profiles. The concentration of both increased linearly above the SMTZ from 50 to $130 \mathrm{cmbsf}\left(7.5\right.$ to $38.6 \mathrm{mM}$ and 3.5 to $36.8 \mathrm{mEq} \mathrm{L}^{-1}$, respectively). Below the SMTZ to the bottom of the core, DIC and TA both increased gradually reaching a maximum of $63.7 \mathrm{mM}$ and $\mathrm{mEq} \mathrm{L}^{-1}$, respectively. $\delta^{13} \mathrm{C}-\mathrm{CH}_{4}$ slightly increased from the top of the core to $87.5 \mathrm{cmbsf}$. Between 87.5 and $150 \mathrm{cmbsf}, \delta^{13} \mathrm{C}-\mathrm{CH}_{4}$ declined rapidly to a minimum of 99.9\%o. Below $150 \mathrm{cmbsf}, \delta^{13} \mathrm{C}-\mathrm{CH}_{4}$ steadily increased reaching $-82.7 \%$ at the bottom of the core. $\delta^{13} \mathrm{C}$-DIC decreased from the top of the core to a minimum (-20.2\%o) at $110 \mathrm{cmbsf}$. Below this minimum, $\delta^{13} \mathrm{C}$-DIC steadily increased to $5.1 \%$ at the bottom of the core. Porewater Fe concentration gradually increased with depth from the minimum at the SMTZ $(3.5 \mu \mathrm{M})$ to the 
maximum at $465 \mathrm{cmbsf}(60.5 \mu \mathrm{M})$. Below $465 \mathrm{cmbsf}$, Fe concentrations decreased towards the base of the core. Similar to Fe, porewater Mn concentrations generally increased between 130 and 465 cmbsf, although two concentration peaks at $70(5.2 \mu \mathrm{M})$ and $465 \mathrm{cmbsf}(5.4 \mu \mathrm{M})$ were observed. $\mathrm{Ba}^{2+}$ concentration increased sharply between 110 and $190 \mathrm{cmbsf}$. Maximum Ba ${ }^{2+}$ concentrations $(\sim 13 \mu \mathrm{M})$ were reached at $240 \mathrm{cmbsf}$, and averaged $10 \mu \mathrm{M}$ below. $\mathrm{Ca}^{2+}$ concentrations decreased from $9.2 \mathrm{mM}$ to $4.9 \mathrm{mM}$ in the upper $190 \mathrm{~cm}$ of the core indicating authigenic carbonate precipitation as a result of increasing alkalinity. Below $190 \mathrm{cmbsf}, \mathrm{Ca}^{2+}$ concentrations averaged 4.6 $\mathrm{mM}$. $\mathrm{Mg}^{2+}$ concentration was $49.8 \mathrm{mM}$ at $70 \mathrm{cmbsf}$ and declined with depth to a minimum (46.3 $\mathrm{mM}$ ) observed at $150 \mathrm{cmbsf}$. Below $150 \mathrm{cmbsf}$, concentrations steadily increased towards the bottom of the core, reaching $55.4 \mathrm{mM}$.

\subsection{Solute fluxes}

$\mathrm{SO}_{4}{ }^{2-}$ fluxes by molecular diffusion down to the SMTZ in PC12 $\left(0.014 \mathrm{mmol} \mathrm{cm}^{-2} \mathrm{yr}^{-1}\right)$ were similar to those in PC13 $\left(0.016 \mathrm{mmol} \mathrm{cm}^{-2} \mathrm{yr}^{-1}\right)$. Below the SMTZ, the flux decreased to $7.0 \times 10^{-4} \mathrm{mmol} \mathrm{cm}^{-2} \mathrm{yr}^{-1}$ at PC12 and was essentially zero at PC13. Therefore, almost all $\mathrm{SO}_{4}{ }^{2-}$ that diffused down to the SMTZ was consumed there. $\mathrm{CH}_{4}$ fluxes directed upwards to the SMTZ were $-0.0089 \mathrm{mmol} \mathrm{cm}^{-2} \mathrm{yr}^{-1}$ at PC12 and $-0.015 \mathrm{mmol} \mathrm{cm}^{-2} \mathrm{yr}^{-1}$ at PC13, demonstrating that AOM accounts for $66 \%$ of the sulfate flux to the SMTZ at PC12 and $97 \%$ at PC13. Organoclastic sulfate reduction in the SMTZ likely accounts for the remaining 34 and $3 \%$. It should be noted that calculations of sulfate reduction rates using linear sulfate concentration profiles often underestimate or even miss surface activity due to replenishment of sulfate by bioirrigation (Fossing et al., 2000) or molecular diffusion in the surface sediments (Jørgensen et al., 2001).

A mass balance of the DIC and sulfate fluxes reveals that 1.66 and 1.46 moles of organic carbon are oxidized per mole of sulfate reduced (Table 4) instead of 2 moles for carbohydrate (i.e. $\left[\mathrm{CH}_{2} \mathrm{O}\right]$ ). Consequently, from Eq. (5), the organic carbon undergoing mineralization has an oxidation state of 0.82 (PC12) and -1.49 (PC13). The organic material is thus more reduced than simple carbohydrate $(o x=0)$. Naturally occurring organic matter in marine sediments has an oxidation state of -0.5 to 0.7 , although values as low as -2.2 have been reported (Jørgensen and Parkes, 2010). The DIC and sulfate fluxes are thus consistent with steady-state degradation of organic matter, although low inputs of methane from deeper sources cannot be ruled out (see Burdige and Komada (2011) for a discussion on this topic). Due to the low oxidation state, more moles of methane are produced than DIC during methanogenesis (Table 3), compared to $1: 1$ when $\left[\mathrm{CH}_{2} \mathrm{O}\right]$ is used as the substrate (e.g., Jørgensen and Kasten, 2006). 
Fluxes of porewater Fe, sulfide, and $\mathrm{Ba}^{2+}$ in PC12 were four orders of magnitude lower than DIC and $\mathrm{SO}_{4}{ }^{2-}$ fluxes. In PC13 no fluxes could be calculated due to discontinuous concentration profiles.

\subsection{Molecular data}

\subsubsection{Microbial diversity in PC13}

A total of 46538 sequences were obtained for PC13 with an average of 1486 and 376 bacterial and archaeal sequences, respectively, per sample (Table S1). Bacterial sequence abundance increased with depth; conversely, archaeal sequences were most abundant near the surface of PC13 (Table S1). In general, bacterial and archaeal diversity declined with depth.

On average, $22 \%$ of bacteria were related to the Chloroflexi class (Fig. 3). The Dehalococcoides were most abundant among the Chloroflexi (not shown). The Obsidian Pool 9 (OP9) group was also highly abundant at all depths except for the surface most sample. The abundance of Coscinodiscophyceae (diatom) chloroplast sequences increased dramatically between 446 and $546 \mathrm{cmbsf}$.

Deltaproteobacteria were most abundant at 15 and $406 \mathrm{cmbsf}$ ( 25\% of sequences) and averaged $\sim 13 \%$ of sequences at all other depths (Fig. 3). From the surface down to the SMTZ (105 cmbsf) in PC13, the majority of Deltaproteobacteria were affiliated with the Syntrophobacterales (Fig. 4). These were less abundant below the SMTZ. Conversely, sequences affiliated with the Desulfobacterales increased below the SMTZ. The Myxococcales were also plentiful in PC13, and in highest relative abundance between 346 and $406 \mathrm{cmbsf}$.

Archaeal sequences in PC13 were dominated by the Thermoplasmata, which averaged of $57 \%$ of sequences (Fig. 5). The majority of these were affiliated with the Marine Benthic Group D (MBG-D, data not shown). The second most abundant archaeal group was related to the Miscellaneous Crenarchaeotal Group (MCG). Sequences affiliated with the Thaumarchaeota, likely Marine Group I, were more abundant below the SMTZ than above it. Although sequences related to the Methanomicrobia, which contains the ANME-2, were observed in PC13, these were not abundant. Methanobacteria were most abundant above the SMTZ, accounting for up to $8 \%$ of sequences at 50 cmbsf. Methanococci accounted for up to $2 \%$ of sequences at $366 \mathrm{cmbsf}$.

\subsubsection{Network analyses}

To visually identify the interactions between operational taxonomic units (OTUs), metabolic rates, and the abiotic environment, correlation distance network analysis was employed. The network for 
PC13 was complex with 300 nodes, representative of biotic and abiotic variables included in the analysis, which had significant correlations with other variables, and $>2800$ edges, representative of correlations between variables. Thus, it was filtered to remove OTU to OTU only correlations. The resulting network diagrams include only OTU-abiotic interactions (including metabolic rate measurements). Negative and positive correlation networks are depicted separately for simplicity (Fig. S1 A and B) as well as combined (Fig. S1 C).

In the positive network (Fig. S1 A), two primary groups of nodes centered on $\mathrm{SO}_{4}{ }^{2-}$ or $\mathrm{CH}_{4}$. The connection between the groups was sulfate reduction rates. In the negative network (Fig. S1 B), the primary groupings of nodes centered on $\mathrm{SO}_{4}{ }^{2-}, \mathrm{CH}_{4}$, and DIC.

There were limited correlations between OTUs and sulfate reduction or AOM rates (Fig. S1). This was possibly due to the processes being carried out by few members of the community, or the patchy distribution of rate data for PC13 (Fig. 1). In the positive network, sulfate reduction was linked indirectly to $\mathrm{CH}_{4}$ through a MCG OTU and $\mathrm{SO}_{4}{ }^{2-}$ through a Chlorobi OTU (Fig. S1 A). In the negative network (Fig. S1 B), sulfate reduction was indirectly coupled to $\mathrm{CH}_{4}$ and $\mathrm{SO}_{4}{ }^{2-}$ through two OTUs related to the Alphaproteobactera and Actinobacteria respectively. AOM was neither directly nor indirectly correlated with $\mathrm{SO}_{4}{ }^{2-}$ or sulfate reduction rates suggesting that in situ, the processes were decoupled. In the positive network, AOM was indirectly linked to $\mathrm{CH}_{4}$ through another Actinobacteria OTU (Solirubrobacterales), which was also highly correlated to $\mathrm{Mg}^{2+}, \mathrm{Mn}$ and DIC. In the negative network, AOM was correlated with 7 bacterial and one archaeal OTUs. The majority of these OTUs was highly correlated to $\mathrm{CH}_{4}$, DIC and Fe as well as $\mathrm{Mg}^{2+}$ and $\mathrm{Mn}$. Two of the bacterial OTUs were affiliated with the Deltaproteobacteria. The archaeal OTU was affiliated with the MSBL1 family of the Methanobacteria, which others have speculated to be involved in methanogenesis in high salinity, anoxic environments (Van der Wielen et al., 2005).

Because the majority of sulfate reducing bacteria were Deltaproteobacteria, the networks were reduced to examine Deltaproteobacterial interactions at the order level (Fig. S2).

Deltaproteobacteria were tightly clustered around $\mathrm{SO}_{4}{ }^{2-}$ in positive networks (Fig. S1a and S2 a). Two Deltaproteobacteria OTUs were also correlated with $\mathrm{CH}_{4}$ in the positive network (Fig. S1a). One was affiliated with the Desulfobacterales and the other with the Myxococcales (Fig. S2a).

Desulfobacteriales abundance increased below the SMTZ (Fig. 4) even though $\mathrm{SO}_{4}{ }^{2-}$ concentrations below the SMTZ were at their lowest (Fig. 1). However, sulfate reduction rates (Fig. 1) and cell abundance ( $\sim 4 \times 10^{9}$ cells g-1; Kirchman et al., 2014) both peaked at between $\sim 260$ and $280 \mathrm{cmbsf}$. The Desulfobacteriales OTU, which was correlated with $\mathrm{CH}_{4}, \mathrm{Fe}, \mathrm{Ba}^{2+}(\rho>0.65)$, and DIC $(\rho=0.50)$, 
and the Myxococcales, which was correlated with $\mathrm{CH}_{4}$ and $\mathrm{Ba}^{2+}$, both peaked in abundance between 280 and $406 \mathrm{cmbsf}$ (2-10\% of sequences).

\subsection{Microbial activity, in vitro}

\subsubsection{Methane production}

Methanogenic activity was determined at in-situ temperature $\left(0.5^{\circ} \mathrm{C}\right)$ in triplicates at two depths (329 and 417 cmbsf) in PC13, respectively, and at three depths (357, 418, and 513 cmbsf) in PC12. All investigated depths were situated below the SMTZ. Continuous $\mathrm{CH}_{4}$ production was detected in all depths (Fig. 6). Methane production rates, derived from linear production curves of each single replicate, ranged between 0.97 and $2.18 \mathrm{nmol} \mathrm{cm}^{-3} \mathrm{~d}^{-1}$

\subsubsection{AOM and sulfate reduction after inhibition with molybdate or BES}

Molybdate and BES (inhibitors for sulfate reduction and methanogenesis/AOM, respectively) were added to sediment slurries from below the SMTZ at PC13 and PC12 to study AOM in $\mathrm{CH}_{4}$-enriched samples and $\mathrm{CH}_{4}$-independent sulfate reduction in $\mathrm{CH}_{4}$-free samples. $\mathrm{AOM}$ and sulfate reduction was detected in all control sediments without inhibitor addition (Fig. 7, w/o BES or Mb). In samples with molybdate addition (Fig. 7, w Mb), sulfate reduction was completely inhibited. In contrast, AOM rates were reduced significantly with molybdate only in 2 samples (PC12, $418 \mathrm{cmbsf}$ and PC13, 417 cmbsf, $p<0.05$ ) while the remaining samples were unaffected. However, in PC13 at $329 \mathrm{cmbsf}$ the $p$ value was compromised by a high standard deviation of the replicates.

In all incubations with BES addition (Fig. 7, w BES), sulfate reduction rates were significantly higher than controls $(p<0.05)$ and increased on average by $37-93 \%$. AOM remained either unaffected by BES addition (PC13 at $329 \mathrm{cmbsf}$ and all samples from PC12, $p>0.05$ ) or was higher (PC13 at 417 cmbsf, p <0.05) compared to controls.

\subsubsection{AOM and sulfate reduction after addition of manganese and iron}

Reducible manganese ( $\mathrm{Na}$-birnessite) and iron (ferric oxyhydroxide) were added to $\mathrm{CH}_{4}$-enriched sediment slurries from below the SMTZ of PC13 and PC12 to study the response of AOM and sulfate 
reduction (Fig. S3). Additionally, inhibition by molybdate and BES was tested in replicate samples. One-way ANOVA revealed that the addition of manganese always significantly $(p<0.005)$ decreased rates of sulfate reduction. In PC13 (329 and $417 \mathrm{cmbsf}$ ), iron addition resulted in a significant ( $p$ $<0.005$ ) increase in sulfate reduction compared to the background. Similar to 3.4.2, BES lead to a significant $(p<0.005)$ increase in sulfate reduction in many treatments irrespective of iron, manganese, or no metal addition, and did not decrease sulfate reduction in any experiment. Molybdate addition resulted in complete inhibition of sulfate reduction in all treatments. Relative to background controls, AOM was not impacted $(p>0.05)$ by amendment with iron or manganese, or by the addition of molybdate or BES. Some random differences occurred between the different treatments (e.g., AOM in PC13 at 417 cmbsf was significantly higher $(p<0.005)$ in treatments with iron compared to treatments with manganese plus BES) but these were too scattered between cores, depths, and treatments to draw clear conclusions. 


\section{DISCUSSION}

The two sediment cores PC13 and PC12 investigated in our study, revealed unusual geochemical profiles and microbial activity below the sulfate-methane transition zone (SMTZ). While in other diffusive settings, anaerobic oxidation of methane (AOM) and sulfate reduction typically peak within the SMTZ and decline to zero in the subjacent methanogenic zone (e.g., Fossing et al., 2000; Iversen and Jørgensen, 1985; Treude et al., 2005a), both processes were active below the SMTZ, i.e. within the methanogenic zone, in our study. Furthermore, (a) sulfate was never completely exhausted below the SMTZ (remained at minimum values between 30 and $500 \mu \mathrm{M}$ ), (b) sulfide and iron were coexistent in many depths below the SMTZ, (c) AOM was not inhibited by molybdate (inhibitor for sulfate reduction) or BES (inhibitor for methanogenesis and AOM) in most of the samples, (d) sulfate reduction was completely inhibited by molybdate, both in the presence and absence of methane, and in many cases increased after BES addition, (e) sulfate reduction declined after manganese addition, and (f) Deltaproteobacteria demonstrated a phylogenetic transition below the SMTZ. These observations provoke several questions and hypotheses about the source of sulfate and the relationship between AOM, sulfate reduction, and methanogenesis below the SMTZ, which will be elaborated below.

\subsection{Potential sources of sulfate below the SMTZ}

\subsubsection{Barite and manganese}

Barite $\left(\mathrm{BaSO}_{4}\right)$ accumulates in marine sediments from different sources such as the water column (marine barite), supersaturated pore fluids (diagenetic barite) or hydrothermal solutions (hydrothermal barite) (Paytan et al., 2002). Barite is usually metastable/unstable in the prevailing geochemical environment below the SMTZ (Riedinger et al., 2006). Sulfate-reducing bacteria have the capability to mobilize sulfate from barite under sulfate-limiting conditions (Baldi et al., 1996; Bolze et al., 1974; Karnachuk et al., 2002) and could therefore promote barite dissolution below the SMTZ to facilitate sulfate reduction. Barium mobilization below the SMTZ has been observed in different marine sediment settings (Riedinger et al., 2006; Torres et al., 1996), and was evident in PC12 by a steep increase of $\mathrm{Ba}^{2+}$ below the SMTZ (Fig. 2). Mobilization probably also occurred in PC13 (Fig. 1), although here a gap in $\mathrm{Ba}^{2+}$ data coverage between 100 and $300 \mathrm{cmbsf}$ limits interpretation. However, the $\mathrm{Ba}^{2+}$ flux of PC12, which was derived from the concentration gradient below the SMTZ, was only $-7.8 \times 10^{-6} \mathrm{mmol} \mathrm{cm}^{-2} \mathrm{yr}^{-1}$ compared to an integrated sulfate reduction rate from the SMTZ to the bottom of the core of $0.64 \mathrm{mmol} \mathrm{cm}^{-2} \mathrm{yr}^{-1}$ (Table 4) and can therefore 
hardly explain the observed sulfate reduction activity below the SMTZ. Nevertheless, $\mathrm{Ba}^{2+}$ concentrations could remain low, even during sulfate mobilization in the presence of sulfate reducers, if other barium compounds such as witherite $\left(\mathrm{BaCO}_{3}\right)$ or barium sulfide $(\mathrm{BaS})$ are formed concomitantly (Baldi et al., 1996). Provided that for every sulfate molecule mobilized from barite, one molecule of sulfide and two molecules of bicarbonate are produced during sulfate reduction, it is conceivable that the actual $\mathrm{Ba}^{2+}$ liberation was masked by secondary precipitation processes according to the following reactions:

Liberation of sulfate from barite via organoclastic sulfate reduction:

$2 \mathrm{CH}_{2} \mathrm{O}+\mathrm{BaSO}_{4} \rightarrow \mathrm{BaCO}_{3}+\mathrm{CO}_{2}+\mathrm{H}_{2} \mathrm{~S}+\mathrm{H}_{2} \mathrm{O}$

Reaction of hydrogen sulfide with barite (Baldi et al., 1996):

$\mathrm{BaSO}_{4}+2 \mathrm{H}_{2} \mathrm{~S} \rightarrow \mathrm{BaS}+\mathrm{SO}_{2}+\mathrm{H}_{2} \mathrm{O}+\mathrm{S}^{0}$

While $\mathrm{SO}_{2}$ produced in Eq. 7 may be microbiologically consumed to form sulfide (Dasu and Sublette, 1989), elemental sulfur could form an additional source for sulfate production via manganese reduction driven by sulfate reducers (Lovley and Phillips, 1994):

$\mathrm{S}^{0}+3 \mathrm{MnO}_{2}+4 \mathrm{H}^{+} \rightarrow \mathrm{SO}_{4}^{2-}+3 \mathrm{Mn}^{2+}+2 \mathrm{H}_{2} \mathrm{O}$

Sulfate produced in Eq. 8 could re-enter organoclastic sulfate reduction processes to produce sulfide, which could re-enter Eq. 7 to further promote formation of elemental sulfur from the reaction with barite. This cycle might proceed until either barite or reducible manganese reservoirs are exhausted. The presence of Mn on the micro-molar level below the SMTZ in both cores (Fig. 1 and 2) suggests that manganese is reduced by an unknown process. Furthermore, the decrease in sulfate reduction observed after addition of manganese in both cores (Fig. S3) indicates that the sulfate-reducing community below the SMTZ is able to use manganese as terminal electron acceptor.

Since the abundance of Desulfobacterales increased below the SMTZ and two OTUs were highly correlated with $\mathrm{Ba}^{2+}$, it is possible that members of this order are specifically adapted to utilize sulfate from barite under low-sulfate conditions. At least one species, Desulfobacterium macestii, is known to produce sulfide from barite under laboratory conditions (Karnachuk et al., 2002). Another member of this order, Desulfobacterium autotrophicum, has been shown to oxidize $S^{0}$ with $\mathrm{Mn}(\mathrm{IV})$ 
(Lovley and Phillips, 1994). It should be kept in mind, however, that pyrotag datasets provide little functional information about potential metabolisms acting in situ.

\subsubsection{Sulfur-iron-carbon reactions}

Iron is suggested to be a key player in sulfate production from sulfide below the SMTZ in the socalled "cryptic sulfur cycle" (Holmkvist et al., 2011). This cycle could provide a sulfate source in our cores as well, which is supported by the abiotic correlations in the network analysis, specifically the highly significant (negative) correlation between sulfide and Fe in PC13. Prerequisite for this pathway of sulfate production is the downward delivery of sulfide to react with deep-buried iron (Holmkvist et al., 2011). The reaction of sulfide with Fe(III) leads to the production of $\mathrm{Fe}^{2+}$ and

thiosulfate $\left(\mathrm{S}_{2} \mathrm{O}_{3}{ }^{2-}\right)$. While thiosulfate is disproportionated into sulfide and sulfate, $\mathrm{Fe}^{2+}$ further reacts with sulfide to form iron sulfide (FeS) and finally pyrite $\left(\mathrm{FeS}_{2}\right)$. This last step is coupled to the simultaneous reduction of $\mathrm{CO}_{2}$ to $\mathrm{CH}_{4}$ with $\mathrm{H}_{2}$. The coexistence of sulfide and Fe below the $\mathrm{SMTZ}$ of both PC13 and PC12 could be evidence for a continuous re-supply of sulfide and ferrous iron at a rate so high that spontaneous FeS formation does not deplete the pool of dissolved constituents. Pyrite, however, was detected only in traces of selected samples from PC13 (123 cmbsf) and PC12 (231 and 594 cmbsf) (Rose et al., 2012).

An alternative pathway for sulfate production could be iron-driven oxidation of elemental sulfur according to the following equation (Lovley and Phillips, 1994):

$\mathrm{S}^{0}+6 \mathrm{Fe}^{3+}+4 \mathrm{H}_{2} \mathrm{O} \rightarrow \mathrm{SO}_{4}^{2-}+6 \mathrm{Fe}^{2+}+8 \mathrm{H}^{+}$

Elemental sulfur could be provided through reactions of sulfide with barite (Eq. 7) or AOM (see below). The above reaction provides a potential source for Fe observed in the porewater below the SMTZ (Fig. 1). An OTU related to the Desulfobacterales was highly correlated with Fe below the SMTZ of PC13. However, in laboratory experiments $D$. autotrophicum, which is an effective iron reducer among the Desulfobacterales, performed no oxidation of $S^{0}$ in the presence of Fe(III) (Lovley and Phillips, 1994). To our knowledge, this metabolism has only been described for Desulfovibrio desulfuricans, a member of the order Desulfovibrionales, which was found only sporadically in PC13 (190 and 466 cmbsf, Fig. 4).

Another pathway to produce sulfate could be sulfur disproportionation in the presence of $\mathrm{Fe}(\mathrm{III})$ according to the following reaction (Thamdrup et al., 1993): 
$\mathrm{S}^{0}+2 \mathrm{FeOOH} \rightarrow \mathrm{SO}_{4}^{2-}+2 \mathrm{FeS}+2 \mathrm{H}^{+}$

In this reaction, iron acts as a sink for sulfide thereby maintaining its concentration low enough to keep the disproportionation process exergonic. The process has been observed in different laboratory studies with members of the order Desulfobacterales (e.g., Finster et al., 1998; Janssen et al., 1996; Lovley and Phillips, 1994). This group revealed higher abundance below the SMTZ in PC13 (Fig. 4). Alternatively to iron, reducible manganese could also act as a sulfide sink during sulfur disproportionation (Thamdrup et al., 1993):

$\mathrm{H}_{2} \mathrm{~S}+\mathrm{MnO}_{2} \rightarrow \mathrm{S}^{0}+\mathrm{Mn}^{2+}+2 \mathrm{OH}^{-}$

4.2 The relationship between AOM, sulfate reduction, and methanogenesis

\subsubsection{AOM and sulfate reduction}

In our in-vitro radiotracer experiments, AOM remained mostly unaffected by the addition of molybdate, while sulfate reduction (both in presence and absence of methane) was inhibited completely (Fig. 7 and S3). This observation suggests that the two processes were not entirely coupled. The results are further supported by molecular analyses. The correlation network, specifically, the lack of direct coupling of AOM to sulfate or sulfate reduction, the dominance and structure of bacterial associations with AOM and abiotic variables (Fig. S1), as well as the minimal abundance of ANME in PC13 (Fig. 3) suggest that AOM could be coupled to manganese and iron reduction in PC13 and involve phylotypes not commonly described in studies of AOM in marine sediments. Although sulfate-dependent AOM generally occurs at a faster rate than experimental manganese- and iron-dependent AOM (Beal et al., 2009), the energy yield from the latter two is 2-4 times greater. However, in our experiments with ${ }^{14} \mathrm{C}$-labelled methane, AOM was not stimulated by addition of either manganese or iron (Fig. S3). Either AOM was not coupled to any of these electron acceptors or natural background concentrations of reducible manganese or iron compounds were not limiting for AOM.

A recent publication demonstrated that members of the ANME group (ANME-2) reduce sulfate during AOM without the direct involvement of sulfate-reducing bacteria (Milucka et al., 2012). As an intermediate, elemental sulfur $\left(\mathrm{S}^{\circ}\right)$ is formed, which further reacts to disulfide:

$\mathrm{CH}_{4}+\frac{8}{6} \mathrm{SO}_{4}^{2-}+\frac{10}{6} \mathrm{H}^{+} \rightarrow \frac{8}{6} \mathrm{~S}^{0}+\frac{14}{6} \mathrm{H}_{2} \mathrm{O}+\mathrm{HCO}_{3}^{-}$ 
$\mathrm{CH}_{4}+4 \mathrm{~S}^{0}+3 \mathrm{H}_{2} \mathrm{O} \rightarrow 5 \mathrm{H}^{+}+4 \mathrm{HS}_{2}^{-}+\mathrm{HCO}_{3}^{-}$

Disulfide is finally disproportionated into sulfate and sulfide by sulfate-reducing bacteria:

$4 \mathrm{HS}_{2}^{-}+4 \mathrm{H}_{2} \mathrm{O} \rightarrow \mathrm{SO}_{4}^{2-}+7 \mathrm{HS}^{-}+5 \mathrm{H}^{+}$

Although the enzymatic mechanisms for this archaeal sulfate reduction to elemental sulfur are unknown, it was suggested to be different from the bacterial pathway (Milucka et al., 2012). If in our study, sulfate reduction below the SMTZ was coupled to AOM, AOM should be similarly responsive to molybdate, since molybdate addition completely inhibited sulfate reduction. Due to its stereochemical similarity to sulfate, molybdate inhibits the first step in sulfate reduction, i.e., the activation of sulfate to adenosine 5'-phosphosulfate (Peck, 1959; Taylor and Oremland, 1979). Molybdate is also a known inhibitor of sulfur disproportionation (Finster et al., 1998) and references therein) and might therefore also inhibit sulfate reducers involved in sulfur dispropotionation during AOM (Eq. 14) or in combination with iron (Eq. 10) and manganese reactions (Eq. 11). However, if AOM was conducted via the pathways proposed by Milucka et al. (2012), it remains unclear, why methane turnover continued in the presence of molybdate, when at the same time all sulfate reduction was interrupted. Furthermore, ${ }^{35} \mathrm{~S}-\mathrm{S}^{0}$ produced during this alternative process should still be detectable via the cold chromium distillation technique (Kallmeyer et al., 2004).

One possible mechanism could be methane oxidation with elemental sulfur as the terminal electron acceptor. In this case, methane oxidation would proceed even if sulfate reduction was inhibited, as long as sufficient reservoirs of elemental sulfur were available. Similar to acetate oxidation with elemental sulfur (Pfennig and Biebl, 1976), the reaction with methane would be:

$\mathrm{CH}_{4}+3 \mathrm{H}_{2} \mathrm{O}+4 \mathrm{~S}^{0} \rightarrow \mathrm{HCO}_{3}^{-}+\mathrm{H}^{+}+4 \mathrm{H}_{2} \mathrm{~S}$

However, following Gibbs free energy caclulations by Thauer et al. (1977) the reaction is endergonic under standard conditions $\left(\Delta G^{\circ}=+24.08 \mathrm{~kJ} \mathrm{~mol}^{-1}\right)$, and possibly even at in situ conditions below the SMTZ (e.g. PC12, 346 cmbsf: $\mathrm{T}=273.5 \mathrm{~K}, \mathrm{H}_{2} \mathrm{~S}=18 \mu \mathrm{M}$, DIC $=72.6 \mathrm{mM}, \mathrm{CH}_{4}=11.65 \mathrm{mM}, \Delta \mathrm{G}=+8.6 \mathrm{~kJ}$ $\mathrm{mol}^{-1}$ ) assuming a pH of 7.2-7.4 for the methanogenic zone (Treude et al., 2005a).

Another potential mechanism could be the oxidation of elemental sulfur with manganese or iron according to Eq. 8 and 9, respectively. In this scenario, the sulfate pool would be balanced, because for every sulfate consumed during AOM one molecule of sulfate would be produced via iron or manganese oxidation. Hence, the reaction would remain untraceable in radiotracer experiments 
using ${ }^{35} \mathrm{~S}$-sulfate. A prerequisite for this reaction would be the metabolic immunity of both methane and iron/manganese oxidizers to molybdate inhibition.

The correlation of Myxococcales with $\mathrm{CH}_{4}$ and $\mathrm{Ba}^{2+}$ between 280 and $406 \mathrm{cmbsf}$ in PC13 (Fig. 4) is interesting with respect to carbon cycling below the SMTZ. Myxococcales are generally strict aerobes, which form fruiting bodies under nutrient limited conditions (Treude et al., 2003b). However, some of the group members have been found to be iron and nitrate reducers (Edlund et al., 2008; Treude et al., 2003b). Although not known as methanotrophs, experimental reactor studies (Murase and Frenzel, 2007) provide direct evidence of incorporation of $\mathrm{CH}_{4}$-derived carbon by members of the Mxyococcales, which may explain correlations between this order and $\mathrm{CH}_{4}$ (Fig. 1).

Surprisingly, AOM, sulfate reduction, and sulfide (Fig. 1 and 2) of both cores revealed no distinct peak within the SMTZ. Since samples were taken in large increments of $20-60 \mathrm{~cm}$, hot spots of AOM activity could have easily been missed (Treude et al., 2005a). Nevertheless, the presence of such hot spot within the SMTZ was evident from carbon isotopic signatures of methane and DIC, showing enriched $\delta^{13} \mathrm{C}_{-} \mathrm{CH}_{4}$ in correlation with depleted $\delta^{13} \mathrm{C}$-DIC as a consequence of carbon isotope fractionation during AOM (Hinrichs et al., 1999). Interestingly, there was the drawdown of $\delta^{13} \mathrm{C}_{-}-\mathrm{CH}_{4}$ just below the SMTZs in both cores, which correlated with a simultaneous drawdown in $\delta^{13} \mathrm{C}$-DIC. We believe that the observed decline in $\delta^{13} \mathrm{C}$ was the result of AOM-mediated carbon isotope equilibration between methane and DIC at low sulfate concentrations ( $<0.5 \mathrm{mM}$, Yoshinaga et al., 2014).

\subsubsection{Sulfate reduction and methanogenesis}

In the present study, sulfate reducers where found active within the methanogenic zone in both exsitu (Fig. 1 and 2) and in-vitro (Fig. 7 and S3) radiotracer experiments. At the same time, methanogens were found active in in-vitro studies at sulfate levels of $500 \mu \mathrm{M}$ (Fig. 6). Both findings were surprising, as sulfate reducers usually outcompete methanogens in marine sediments due to a higher substrate affinity with respect to $\mathrm{H}_{2}$ (Kristjansson et al., 1982) and acetate (Schönheit et al., 1982), unless non-competitive substrates are available (Oremland et al., 1982) or competitive substrates are present in excess (Treude et al., 2009). Sulfate reducers that utilize hydrogen and acetate are still able to compete with methanogens at sulfate levels between 60 and $150 \mu \mathrm{M}$ (Lovley and Klug, 1983). In lakes, methanogens were found to outcompete sulfate reducers at sulfate concentrations below $30 \mu \mathrm{M}$ (Kuivila et al., 1989), which corresponds to the lowest 
concentration measured in our study. The various potential sources for sulfate below the SMTZ were discussed in detail above. A remaining question is the relationship between sulfate-reducing bacteria and methanogenic archaea. Interestingly, during in-vitro incubations, sulfate reduction was often higher in presence of the methanogen inhibitor BES (Fig.7 and S3). We have no confirmation of a successful methanogen inhibition and BES is not an inhibitor to all methanogens (Santoro and Konisky, 1987); however, stimulation of sulfate reduction during BES addition (Fig. 7 and S3) indicate that sulfate reducers took advantage of the inhibitor. Possibly, liberation of sulfate from mineral sources was limiting creating a strong competition between sulfate reducers and methanogens for electron donors. Consequently, sulfate reducers were probably able to increase their turnover rates while methanogens were inhibited.

The dramatic decline in sulfate reduction rates after manganese addition (Fig. S3) provokes three hypotheses. First, active sulfate reducers preferred electron acceptors with a higher energy gain when offered, maybe not only to yield more energy but also to compete with methanogens. Desulfotomaculum reducens (Tebo and Obraztsova, 1998), order: Clostridiales), and Desulfovibrio (Coleman et al., 1993), order: Desulfovibrionales) are examples of bacteria capable of switching between sulfate and manganese or iron reduction, respectively; however, members of Clostridiales were not present in PC13 and Desulfovibrionales represented only a minority below the SMTZ. Second, classical manganese reducers outcompeted sulfate reducers by keeping substrate concentrations at levels lower than thresholds required by sulfate-reducing bacteria (compare with Chapelle and Lovley, 2005). Third, manganese addition stimulated manganese-dependent sulfide oxidation (King, 2006). As a consequence, continuous re-oxidation of ${ }^{35} \mathrm{~S}$-sulfide to ${ }^{35} \mathrm{~S}$-sulfate masked sulfate-reduction activity during the radiotracer incubations.

As recently observed by others (LeLoup et al., 2009; LeLoup et al., 2007) sulfate-reducing bacteria may be as abundant in deep sulfate depleted sediments as they are in surface sediments, where sulfate concentrations are highest, and display distinct phylogenetic zonation with respect to depth and sulfate concentration. In our study, the SMTZ marked a distinct transition in Deltaproteobacteria composition (Fig. 4). Sequences related to the sulfate-reducing Syntrophobacterales were highly abundant above the SMTZ, while sequences related to the Desulfobacterales were more abundant below. This transition, the relatively high abundance of sulfate-reducing bacteria related OTUs in the methanogenic zone, and the direct evidence of sulfate reduction at depth in PC12 and PC13 provide supporting evidence for the occurrence of sulfate reduction in sediments with low sulfate concentration. As has been noted elsewhere, such 
observations of high abundance of sulfate-reducing bacteria and sulfate reduction rates in deep sediments equal to or even exceeding that in surface sediments, suggest that sulfate-reducing bacteria may have a more expansive role in the utilization of organic matter in methane containing sediments (LeLoup et al., 2007).

4.3 Mass balances and postulation of a complex sulfur cycling network below the SMTZ

The potential significance of different sulfate sources discussed under 4.1 with regard to measured sulfate reduction and AOM rates below the SMTZ can be estimated. The stoichiometry in Table 3 shows that 8 moles of ferric iron are required to oxidize 1 mole of $\mathrm{H}_{2} \mathrm{~S}$ to $\mathrm{SO}_{4}{ }^{2-}$ or 1 mole of $\mathrm{CH}_{4}$ to DIC. From the sum of sulfate reduction (LSR) (Table 4), an iron flux of 5.1 and $1.5 \mathrm{mmol} \mathrm{cm}^{-2} \mathrm{yr}^{-1}$ at PC12 and PC13, respectively, is therefore needed to produce an amount of $\mathrm{SO}_{4}{ }^{2-}$ equivalent to $\Sigma \mathrm{SR}$. Similarly, additional iron fluxes of 3.6 and $1.5 \mathrm{mmol} \mathrm{cm}^{-2} \mathrm{yr}^{-1}$ at PC12 and PC13, respectively, would be required to account for the sum of $A O M(\Sigma A O M)$. The theoretical fluxes of iron to the sediment can be obtained by multiplying the iron content (2.3\%; (Trefry et al., 2003) by the bulk sediment mass accumulation rates, $F_{\text {sed, }}$ in Table 4 . The resulting values are approximately $0.1 \mathrm{mmol} \mathrm{cm}^{-2} \mathrm{yr}^{-1}$ for PC12 and PC13. These are only 1.9 and $6.9 \%$ of the required iron fluxes to sustain the sulfate reduction below the SMTZ in PC12 and PC13. With regards to AOM, the iron flux could account for only $2.7 \%$ (PC12) and $6.5 \%$ (PC13) of 5 AOM. Mass balances match even less for manganese and barium, which have much lower concentrations in the sediment (manganese $\sim 294 \mu \mathrm{g} \mathrm{g}^{-1}$, barium $\sim 460 \mu \mathrm{g} \mathrm{g}^{-1}$ (Trefry et al., 2003). Here, manganese and barium fluxes could account for only a per mill or less to either $\Sigma$ SR or $\Sigma$ AOM.

The mismatch of measured methane and sulfate turnover rates with fluxes of iron, manganese, and barium could have several possible explanations:

(A) Sulfate reduction rates were overestimated, because sulfate concentrations measured after rhizon extractions were higher than in situ due to oxidation of sulfide to sulfate during sampling. We are confident that we can exclude this possibility, because rhizon samplers were flushed with sample prior to collection, and samples for sulfate measurement were preserved in cadmium nitrate to prevent sulfide oxidation during storage. Furthermore, even if sulfate reduction rates were overestimated, AOM rates, which were calculated independently from sulfate concentrations via methane, would have remained unaffected.

(B) The observed AOM was only the enzymatic re-reaction of methanogenesis. Radiotracer turnover data provides only little information about the involved process. Methanogenic 
cultures were shown to turn ${ }^{14} \mathrm{C}$-labelled methane into carbon dioxide during methanogenesis (Zehnder and Brock, 1979). The process accounted for $0.001-0.3 \%$ of methane production. In methanogenic sludge, the percentage increased to 8\% (Zehnder and Brock, 1980). The possibility that AOM below the SMTZ of PC13 and PC12 was only part of methanogenesis as a form of an enzymatic re-reaction seems evident; however, in-vitro methane production (Fig. 6) and ex situ AOM (Fig. 1 and 2) rates were similar (0.5-2 $\left.\mathrm{nmol} \mathrm{cm}^{-3} \mathrm{~d}^{-1}\right)$. Therefore methanogenesis can hardly explain the observed methane turnover.

(C) Sulfate reduction and AOM rates were overestimated in depth-integrated calculations, because the activity was in reality too patchy. Since rates were determined only in selected depth sections, values of missing depth sections had to be interpolated to achieve full depth integration. If, however, the activity below the SMTZ was distributed non-uniformly, which is indicated by the heterogeneity of rates, integrated rates could be overestimated.

Overestimation is implied by the mismatch between integrated AOM and DIC fluxes (Table 4). If we assume the extreme case that sulfate reduction and AOM were active only in the measured depths and inactive in the gaps, integrated rates below the SMTZ would drop by 1 to 2 orders of magnitudes: 0.001 (sulfate reduction) and 0.004 (AOM) mmol cm${ }^{-2} \mathrm{yr}^{-1}$ in PC13 and 0.03 (sulfate reduction) and 0.02 (AOM) $\mathrm{mmol} \mathrm{cm}^{-2} \mathrm{yr}^{-1}$ in PC12. In this case, sulfate supply could be easily provided by iron reactions alone. Since we are unable to predict the actual rates in nonmeasured depths, true sulfate demand below the SMTZ remains unknown.

Irrespective of whether we missed an alternative sulfate source, our study indicates that sulfate may be entering and exiting reactions at different stations in a complex sulfur cycle below the SMTZ. Reactions consuming sulfate may include (1) organoclastic sulfate reduction with barite (Eq. 6), (2) reaction of barite with sulfide (Eq. 7), and (3) sulfate-dependent AOM (Eq. 1 or 12). In contrast, (4) reaction of sulfide with iron (Holmkvist et al., 2011), (5) sulfur oxidation with manganese (Eq. 8) or iron (Eq. 9), (6) sulfur dispropotionation with manganese (Eq. 11) or iron (Eq. 10), and (7) disulfide dispropotionation (Eq. 14) represent potential sulfate sources. On the basis of the iron-based cryptic sulfur cycle proposed by Holmkvist et al. (2011), we therefore attempt to extend this model by incorporating reactions with barite and manganese, allowing for more diverse sulfur cycling below the SMTZ (Fig. 8). It should be kept in mind that barite and manganese rarely reach the magnitude of iron deposits in most ordinary marine sediments (e.g., McManus et al., 1998; Trefry et al., 2003; Windom et al., 1989) and can therefore probably explain only a minor fraction of sulfate reduction below the SMTZ. However, aside from the 
meager pelagic origin, massive barite deposits are known to form at cold-seep (Greinert et al., 2002; Torres et al., 2003) and hydrothermal systems (Hein et al., 2000; Koski et al., 1985; Moore and Stakes, 1990) through the reaction of advecting barium-loaded fluids with sulfate-rich porewater or seawater. Additional barite sources may also include the drainage of deep continent-related fluids (Aquilina et al., 1997). Massive manganese oxide deposits can form in hydrothermal systems (Cronan et al., 1982; Hein et al., 2000), in black shale basins during marine transgressions (Force and Cannon, 1988; Frakes and Bolton, 1992; Huckriede and Meischner, 1996), and related to oceanic anoxic events (Glasby, 1988) and references therein). Burial of manganese nodules may represent another pathway for introducing manganese sources into deeper sediment layers (Pattan and Parthiban, 2007). All of the above barite and manganese deposits bear, after burial, the potential to fuel organoclastic sulfate reduction or AOM below the SMTZ. 


\section{CONCLUSIONS}

In the present study, simultaneous methanogenic, methanotrophic, and sulfate-reducing activity were detected below the SMTZ in two sediment cores taken along a depth transect on the AlaskanBeaufort continental margin. In both cores, sulfate was not completely exhausted within the SMTZ. Although microbial key players and metabolic mechanisms could not be identified unambiguously, the data suggest the occurrence of sulfur cycling below the SMTZ potentially involving iron, manganese, and barite. Inhibition experiments pointed to a decoupling of AOM and sulfate reduction and a strong competition between sulfate reducers and methanogens. A coupling of AOM to manganese or iron reduction was indicated by correlation network analyses but was not evident from stimulation experiments. Since classical representatives of archaeal methanotrophs (ANME) were not abundant, the involvement of so far unknown groups in AOM should be considered. The predominant resistance of AOM activity against the inhibitors molybdate and BES further indicate deviations from known enzymatic pathways. In summary, our observations together with studies by, e.g., Dale et al. (2008), Holmkvist et al. (2011), Knab et al. (2009), and LeLoup et al. (2009)) demonstrate that the classical redox cascade of electron acceptors (Jørgensen, 2000) and strict vertical separation of processes according to their energy yields can be violated even in diffusiondominated marine sediments and might instead be more strongly coupled to mineralogy. Future studies should seek to quantify sources for such anomalies. Inconclusive datasets that deviate from the standard textbook ideology may not necessarily reflect sampling and analytical artifacts or arise from non-steady state diagenesis. 


\section{ACKNOWLEDGEMENTS}

We thank the captain and crew of USCGC Polar Sea and C. Verlinden, R. Downer and L. Bryant for field assistance. We thank R. Plummer, D. Gustafson, J. Hommer, B. Domeyer, A. Bleyer, R. Suhrberg, and the MITAS shipboard scientific party for laboratory assistance and P. Gillevet for insight on network analysis. R. Thauer is thanked for stimulating discussions. We thank three reviewers for their valuable comments. TT and SK were supported by the Cluster of Excellence 'The Future Ocean' funded by the German Research Foundation. Geochemical work was supported by Office of Naval Research Code 33 and Department of Energy, National Energy Technology Laboratory, Morgantown WVA. LJH was supported by the Naval Research Laboratory (NRL) Chemistry Division Young Investigator Program. Ship time was funded by the NRL platform support program. 


\section{REFERENCES}

Aquilina, L., Dia, A.N., Boulégue, J., Bourgois, J., Fouillac, A.M., 1997. Massive barite deposits in the convergent margin off Peru: Implications for fluid circulation within subduction zones. Geochim. Cosmochim. Acta 61, 1233-1245.

Baldi, F., Pepi, M., Burrini, D., Kniewald, G., Scali, D., Lanciotti, E., 1996. Dissolution of barium from barite in sewage sludges and cultures of Desulfovibrio desulfuricans. Appl. Environ. Microbiol. 62, 2398-2404.

Barberan, A., Bates, S.T., Casamayor, E.O., Fierer, N., 2012. Using network analysis to explore cooccurrence patterns in soil microbial communities. ISME Journal 6, 343-351.

Barnes, R.O., Goldberg, E.D., 1976. Methane production and consumption in anoxic marine sediments. Geology 4, 297-300.

Beal, E.J., House, C.H., Orphan, V.J., 2009. Manganese- and iron-dependent marine methane oxidation. Science 325, 184-187.

Boetius, A., Ferdelman, T., Lochte, K., 2000. Bacterial activity in sediments of the deep Arabian Sea in relation to vertical flux. Deep-Sea Res. II 47, 2835-2875.

Bolze, C.E., Malone, P.G., Smith, M.J., 1974. Microbial mobilization of barite. Chemical Geology 13, 141143.

Boudreau, B.P., 1997. Diagenetic models and their implementation. Springer Verlag.

Burdige, D.J., Komada, T., 2011. Anaerobic oxidation of methane and the stoichiometry of remineralization processes in continental margin sediments. Limnol. Oceanogr. 56, 1781-1796.

Chapelle, F.H., Lovley, D.R., 2005. Competitive Exclusion of Sulfate Reduction by Fe(III)-Reducing Bacteria: A Mechanism for Producing Discrete Zones of High-Iron Ground Water. Groundwater 30, 29-36.

Claypool, G.E., Kaplan, I.R., 1974. The origin and distribution of methane in marine sediments, in: Kaplan, I., Isaacs, R. (Eds.), 1. Marine sediments - Gas content - Congresses. Plenum Press, New York, pp. 99-139.

Cline, J.D., 1969. Spectrophometric determination of hydrogen sulfide in natural waters. Limnol. Oceanogr. 14, 454-458.

Coffin, R.B., Smith, J.P., Plummer, R.E., Yoza, B., Larsen, R.K., Millholland, L.C., Montgomery, M.T., 2013. Spatial variation in shallow sediment methane sources and cycling on the Alaskan Beaufort Sea shelf/slope. Mar. Petr. Geol. 45, 186-197.

Coleman, M.L., Hedrick, D.B., Lovley, D.R., White, D.C., Pye, K., 1993. Reduction of Fe(III) in sediments by sulphate-reducing bacteria. Nature 361.

Cronan, D.S., Glasby, G.P., Moorby, S.A., Thomson, J., Knedler, K.A., McDougall, J.C., 1982. A submarine hydrothermal manganese deposit from the south-west Pacific island arc. Nature 298, 456-458. 
Dale, A.W., Regnier, P., Knab, N.J., Jørgensen, B.B., Van Cappellen, P., 2008. Anaerobic oxidation of methane (AOM) in marine sediments from the Skagerrak (Denmark): Il. Reaction-transport modeling. Geochim. Cosmochim. Acta 72, 2880-2894.

Darby, D.A., Ortiz, J., Polyak, L., Lund, S., Jakobsen, M., Woodgate, R.A., 2009. The role of currents and sea ice in both slowly deposited central Arctic and rapidly deposited Chukchi-Alaskan margin sediments. Glob. Planet. Change 68, 58-72.

Dasu, B.N., Sublette, K.L., 1989. Reduction of sulfur dioxide by Desulfovibrio desulfuricans in co-culture with fermentative heterotrophs. Biotechnol. Bioengineer. 34, 405-409.

Edlund, A., Hardeman, F., Jannson, J.K., Sjoling, S., 2008. Active bacterial community structure along vertical redox gradients in Baltic Sea sediment. Environ. Microbiol. 10, 2051-2063.

Ettwig, K.F., Butler, M.K., Le Paslier, D., Pelletier, E., Mangenot, S., Kuypers, M.M.M., Schreiber, F., Dutilh, B.E., Zedelius, J., De Beer, D., Gloerich, J., Wessels, H.J.C.T., Alen, T.v., Luesken, F., Wu, M.L., PasSchoonen, v.d., K.T., Op den Camp, H.J.M., Janssen-Megens, E.M., Francoijs, K.-J., Stunnenberg, H., Weissembach, J., Jetten, M.S.M., Strous, M., 2010. Nitrite-driven anaerobic methane oxdation by oxygenic bacteria. Nature 464, 544-550.

Feng, Q., Liu, L., Yanagisawa, K., 2000. Effects of synthesis parameters on the formation of birnessitetype manganese oxides. J. Material Sci. Let. 19, 1567-1570.

Finster, K., Liesack, W., Thamdrup, B., 1998. Elemental sulfur and thiosulfate disproportionation by Desulfocapsa sulfoexigens sp. nov., a new anaerobic bacterium isolated from marine surface sediment. Appl. Environ. Microbiol. 64, 119-125.

Force, E.R., Cannon, W.F., 1988. Depositional model for shallow-marine manganese deposits around black shale basins. Econom. Geol. 83, 93-117.

Fossing, H., Ferdelman, T.G., Berg, P., 2000. Sulphate reduction and methane oxidation in continental sediments influenced by irrigation (South-East Antlantik off Namibia). Geochim. Cosmochim. Acta 64, 897-910.

Frakes, L., Bolton, B.R., 1992. Effects of ocean chemistry, sea level, and climate on the formation of primary sedimentary manganese ore deposits. Econom. Geol. 87, 1207-1217.

Gilbert, J.A., Steele, J.A., Caporaso, J.F.G., Steinbruch, L., Reeder, J., Temperton, B., Huse, S., McHardy, A.C., Knight, R., Joint, I., Somerfield, P., Fuhrman, J.A., Field, D., 2012. Defining seasonal marine microbial community dynamics. ISME Journal 6, 298-308.

Glasby, G.P., 1988. Manganese deposition through geological time: dominance of the Post-Eocene deepsea environment. Ore Geol. Rev. 4, 135-144.

Greinert, J., Bollwerk, S.M., Derkachev, A., Bohrmann, G., Suess, E., 2002. Massive barite deposits and carbonate mineralization in the Derugin Basin, Sea of Okhotsk: precipitation processes at cold seep sites. Earth Planet. Sci. Lett. 203, 165-180. 
Gunsalus, R.P., Roemesser, J.A., Wolfe, R.S., 1978. Preparation of coenzyme M analogues and their activity in the methyl coenzyme $M$ reductase system of Methanobacterium thermoautotrophicum. Biochemistry 17, 2374-2377.

Hamdan, L.J., Coffin, R.B., Sikaroodi, M., Greinert, J., Treude, T., Gillevet, P.M., 2013. Ocean currents shape the microbiome of Arctic marine sediments. ISME Journal 7, 685-696.

Hamdan, L.J., Gillevet, P.M., Pohlman, J.W., Sikaroodi, M., Greinert, J., Coffin, R.B., 2011. Diversity and biogeochemical structuring of bacterial communities across the Porangahau ridge accretionary prism, New Zealand. FEMS Microb. Ecol. 77, 518-532.

Hanson, R.S., Hanson, T.E., 1996. Methanotrophic bacteria. Microbiol. Rev. 60, 439-471.

Hein, J.R., Stamatakis, M.G., Dowling, L.S., 2000. Trace metal-rich Quaternary hydrothermal manganese oxide and barite deposit, Milos Island, Greece Appl. Earth Sci. 109, 67-76.

Hinrichs, K.-U., Hayes, J.M., Sylva, S.P., Brewer, P.G., De Long, E.F., 1999. Methane-consuming archaebacteria in marine sediments. nature 398, 802-805.

Hoehler, T.M., Alperin, M.J., Albert, D.B., Martens, C.S., 1994. Field and laboratory studies of methane oxidation in an anoxic marine sediments: evidence for methanogen-sulphate reducer consortium. Global Biochem. Cycles 8, 451-463.

Hoehler, T.M., Borowski, W.S., Alperin, M.J., Rodriguez, N.M., Paull, C.K., 2000. 8. Model, stable isotope, and radiotracer characterization of anaerobic methane oxidation in gas hydrate-bearing sediments of the Blake Ridge, in: Matsumoto, P.C.K., Wallace, P.J., Dillon, W.P. (Eds.), Proceedings of the Ocean Drilling Program, Scientific Results, pp. 79-85.

Holmkvist, L., Ferdelman, T.G., Jørgensen, B.B., 2011. A cryptic sulfur cycle driven by iron in the methane zone of marine sediments (Aarhus Bay, Denmark). Geochim. Cosmochim. Acta 75, 3581-3599.

Huckriede, H., Meischner, D., 1996. Origin and environment of manganese-rich sediments within blackshale basins Geochim. Cosmochim. Acta 60, 1399-1413.

Ivanenkov, V.N., Lyakhin, Y.I., 1978. Determination of total alkalinity in seawater, in: Bordovsky, O.K., Ivanenkov, V.N. (Eds.), Methods of Hydrochemical Investigations in the Ocean. Nauka Publ. House, pp. 110-114.

Iversen, N., Jørgensen, B.B., 1985. Anaerobic methane oxidation rates at the sulphate-methane transition in marine sediments from Kattegat and Skagerrak (Denmark). Limnol. Oceanogr. 30, 944-955.

Janssen, P.H., Schuhmann, A., Bak, F., Liesack, W., 1996. Disproportionation of inorganic sulfur compounds by the sulfate-reducing bacterium Desulfocapsa thiozymogenes gen. nov., sp. nov. Arch. Microbiol. 166, 184-1932.

Jørgensen, B.B., 2000. Bacteria and marine biogeochemistry, in: Schulz, H.D., Zabel, M. (Eds.), Marine biogeochemistry. Springer Verlag, Berlin, pp. 173-201. 
Jørgensen, B.B., Kasten, S., 2006. Sulfur cycling and methane oxidation, in: Schulz, H.D., Zabel, M. (Eds.), Marine Geochemistry. Springer Berlin Heidelberg, pp. 271-309.

Jørgensen, B.B., Parkes, R.J., 2010. Role of sulfate reduction and methane production by organic carbon degradation in eutrophic fjord sediments (Limfjorden, Denmark). Limnol. Oceanogr. 55, 1338-1352.

Jørgensen, B.B., Weber, A., Zopfi, J., 2001. Sulphate reduction and anaerobic methane oxidation in Black Sea sediments. Deep-Sea Res. I 48, 2097-2120.

Joye, S.B., Boetius, A., Orcutt, B.N., Montoya, J.P., Schulz, H.N., Erickson, M.J., Logo, S.K., 2004. The anaerobic oxidation of methane and sulfate reduction in sediments from Gulf of Mexico cold seeps. Chem. Geol. 205, 219-238.

Kallmeyer, J., Ferdelman, T.G., Weber, A., Fossing, H., Jørgensen, B.B., 2004. A cold chromium distillation procedure for radiolabeled sulfide applied to sulfate reduction measurements. Limnol. Oceanogr.: Methods 2, 171-180.

Karnachuk, O.V., Kurochkina, S.Y., Tuovinen, O.H., 2002. Growth of sulfate-reducing bacteria with solidphase electron acceptors. Appl. Microbiol. Biotechnol. 58, 482-486.

King, G.M., 2006. Effects of added manganic and ferric oxides on sulfate reduction and sulfide oxidation in intertidal sediments. FEMS Microbiol. Lett. 73, 131-138.

Kirchman, D.L., Hanson, T.E., Cottrell, M.T., Hamdan, L.J., 2014. Metagenomic analysis of organic matter degradation in methane-rich Arctic Ocean sediments. Limnol. Oceanogr. 59, 548-559.

Knab, N.J., Cragg, B.A., Hornibrook, E.R., Holmquist, L., Pancost, R.D., Borowski, W.S., Parkes, R.J., Jørgensen, B.B., 2009. Regulation of anaerobic methane oxidation in sediments of the Black Sea. Biogeosciences 6, 1505-1518.

Knittel, K., Boetius, A., 2009. Anaerobic oxidation of methane: progress with an unknown process. Annu. Rev. Microbiol. 63, 311-334.

Koski, R.A., Lonsdale, P.F., Shanks, W.C., Berndt, M.E., Howe, S.S., 1985. Mineralogy and geochemistry of a sediment-hosted hydrothermal sulfide deposit from the Southern Trough of Guaymas Basin, Gulf of California. J. Geophys. Res.)=, 6695-6707.

Kristjansson, J.K., Schönheit, P., Thauer, R.K., 1982. Different $K_{s}$ values for hydrogen of methanogenic bacteria and sulfate reducing bacteria: an explanation for the apparent inhibition of methanogenesis by sulfate. Arch. Microbiol. 131, 278-282.

Kuivila, K.M., Murray, J.W., Devol, A.H., 1989. Methane production, sulfate reduction and competition for substrates in the sediments of Lake Washington. Geochim. Cosmochim. Acta 53, 409-416.

LeLoup, J., Fossing, H., Kohls, K., Holmkvist, L., Borowski, C., Jørgensen, B.B., 2009. Sulfate-reducing bacteria in marine sediments (Aarhus Bay, Denmark): abundance and diversity related to geochemical zonation. Environ. Microbiol. 11, 1278-1291. 
LeLoup, J., Loy, A., Knab, N.J., Borowski, C., Wagner, M., Jørgensen, B.B., 2007. Diversity and abundance of sulfate-reducing microorganisms in the sulfate and methane zones of a marine sediment, Black Sea. Environ. Microbiol. 9, 131-142.

Lovley, D.R., Klug, M.J., 1983. Sulfate reducers can outcompete methanogens at freshwater sulfate concentrations. Appl. Environ. Microbiol. 45, 187-192.

Lovley, D.R., Phillips, E.J.P., 1986. Organic matter mineralization with reduction of ferric iron an anaerobic sediments. Appl. Environ. Microbiol. 51, 683-689.

Lovley, D.R., Phillips, E.J.P., 1994. Novel process for anaerobic sulfate production from elemental sulfur by sulfate-reducing bacteria. Appl. Environ. Microbiol. 60, 2394-2399.

McManus, J., Berelson, W.M., Klinkhammer, G.P., Johnson, K.S., Coale, K.H., Anderson, R.F., Kumar, N., Burdige, D.J., Hammond, D.E., Brumsack, H.J., McCorkle, D.C., Rushdi, A., 1998. Geochemistry of barium in marine sediments: Implications for its use as a paleoproxy. Geochim. Cosmochim. Acta 62, 3453-3473. Milucka, J., Ferdelman, T., Polerecky, L., Franzke, D., Wegener, G., Schmid, M., Lieberwirth, I., Wagner, M., Widdel, F., Kuypers, M.M.M., 2012. Zero-valent sulphur is a key intermediate in marine methane oxidation. Nature 491, 541-546.

Moore, W.S., Stakes, D., 1990. Ages of barite-sulfide chimneys from Mariana Trough. Earth Planet. Sci. Lett. 100, 265-274.

Murase, J., Frenzel, P., 2007. A methane-driven microbial food web in a wetland rice soil. Environ. Microbiol. 9, 3025-3034.

Niewöhner, C., Hensen, C., Kasten, S., Zabel, M., Schulz, H.D., 1998. Deep sulfate reduction completely mediated by anaerobic methane oxidation in sediments of the upwelling area off Namibia. Geochim. Cosmochim. Acta 62, 455-464.

Oremland, R.S., Capone, D.G., 1988. Use of specific inhibitors in biogeochemistry and microbial ecology, in: Marshall, K.C. (Ed.), Advances in microbial ecology. Pleneum Press, New York, pp. 285-383.

Oremland, R.S., Marsh, L.M., Polcin, S., 1982. Methane production and simultaneous sulphate reduction in anoxic, salt marsh sediments. Nature 296, 143-145.

Orphan, V.J., House, C.H., Hinrichs, K.-U., McKeegan, K.D., De Long, E.F., 2001. Methane-consuming Archaea revealed by directly coupled isotopic and phylogenetic analysis. Science 293, 484-487.

Pattan, J.N., Parthiban, G., 2007. Do manganese nodules grow or dissolve after burial? Results from the Central Indian Ocean Basin. J. Asian Earth Sci. 30, 696-705.

Paytan, A., Mearon, S., Cobb, K., Kastner, M., 2002. Origin of marine barite deposits: Sr and S isotope characterization. Geology 30, 747-750.

Peck, H.D., 1959. The ATP-dependent reduction of sulfate with hydrogen in extracts of Desulfovibrio desulfuricans. PNAS 45, 701-708. 
Pernthaler, A., Dekas, A.E., Brown, C.T., Goffredi, S.K., Embaye, T., Orphan, V., 2008. Diverse syntrophic partnerships from deep-sea methane vents revealed by direct cell capture and metagenomics. Proc. Acad. Nat. Sci. Philadelphia 105, 7052-7057.

Pfennig, N., Biebl, H., 1976. Desulfuromonas acetoxidans gen. nov. and sp. nov., a new anaerobic, sulfurreducing, acetate-oxidizing bacterium. Arch. Microbiol. 110, 3-12.

Riedinger, N., Kasten, S., Gröger, J., Franke, C., Pfeifer, K., 2006. Active and buried authigenic barite fronts in sediments from the Eastern Cape Basin. Earth Planet. Sci. Lett. 241, 876-887.

Rose, K., Johnson, J.E., Phillips, S.C., Reed, A., Disenhof, C., Presley, J., 2012. MITAS-2009 Expedition, U.S. Beaufort Shelf and Slope - Lithostratigraphy Data Report; NETL-TRS-2-2012. U.S. Department of Energy, National Energy Technology Laboratory, p. 136.

Santoro, N., Konisky, J., 1987. Characterization of bromoethanesulfonate-resistant mutants of Methanococcus voltae: evidence of a coenzyme M transport system. J. Bacteriol. 169, 660-665.

Schönheit, P., Kristjansson, J.K., Thauer, R.K., 1982. Kinetic mechanism for the ability of sulfate reducers to out-compete methanogens for acetate. Arch. Microbiol. 132, 285-288.

Seeberg-Elverfeldt, J., Schlüter, M., Feseker, T., Kölling, M., 2005. Rhizon sampling of porewater near the sediment-water interface of aquatic systems. Limnol. Oceanogr.: Methods 3, 361-371.

Steele, J.A., Countway, P.D., Xia, L., Vigil, P.D., Beman, J.M., Kim, D.Y., Chow, C.-E.T., Sachdeva, R., Jones, A.C., Schwalbach, M.S., Rose, J.M., Hewson, I., Patel, A., Sun, F., Caron, D.A., Fuhrman, J.A., 2011. Marine bacterial, archaeal and protistan association networks reveal ecological linkages. ISME Journal 5, 14141425.

Taylor, B.F., Oremland, R.S., 1979. Depletion of adenosine triphosphate in Desulfovibrio by oxyanions of group VI elements. Curr. Microbiol. 3, 101-103.

Tebo, B.M., Obraztsova, A.Y., 1998. Sulfate-reducing bacterium grows with $\mathrm{Cr}(\mathrm{VI}), \mathrm{U}(\mathrm{VI}), \mathrm{Mn}(\mathrm{IV})$, and $\mathrm{Fe}(\mathrm{III})$ as electron acceptors. FEMS Microbiol. Lett. 162, 193-198.

Thamdrup, B., Finster, K., Hansen, J.W., Bak, F., 1993. Bacterial disproportionation of elemental sulfur coupled to chemical reduction of iron and manganese. Appl. Environ. Microbiol. 59, 101-108.

Thauer, R.K., Jungermann, K., Decker, K., 1977. Energy conversation in chemotrophic anaerobic bacteria. Bacteriol. Rev. 41, 100-180.

Torres, M.E., Bohrmann, G., Dubé, T.E., 2003. Formation of modern and Paleozoic stratiform barite at cold methane seeps on continental margins. Geology 31, 897-900.

Torres, M.E., Brumsack, H.J., Bohrmann, G., Emeis, K.C., 1996. Barite fronts in continental margin sediments: A new look at barium remobilization in the zone of sulfate reduction and formation of heavy barites in diagenetic fronts. Chem. Geol. 127, 125-139.

Trefry, J.H., Rember, R.D., Trocine, R.P., Brown, J.S., 2003. Trace metals in sediments near offshore oil exploration and production sites in the Alaskan Arctic. Environ. Geol. 45, 149-160. 
Treude, N., Rosencrantz, D., Liesack, W., Schnell, S., 2003b. Strain FAc12, a dissimilatory iron-reducing member of the Anaeromyxobacter subgroup of Myxococcales. FEMS Microb. Ecol. 44, 261-269.

Treude, T., Krüger, M., Boetius, A., Jørgensen, B.B., 2005b. Environmental control on anaerobic oxidation of methane in the gassy sediments of Eckernförde Bay (German Baltic). Limnol. Oceanogr. 50, 17711786.

Treude, T., Niggemann, J., Kallmeyer, J., Wintersteller, P., Schubert, C.J., Boetius, A., Jørgensen, B.B., 2005a. Anaerobic oxidation of methane in the sulfate-methane transition along the Chilean continental margin. Geochim. Cosmochim. Acta 69, 2767-2779.

Treude, T., Smith, C.R., Wenzhoefer, F., Carney, E., Bernardino, A.F., Hannides, A.K., Krueger, M., Boetius, A., 2009. Biogeochemistry of a deep-sea whale fall: sulfate reduction, sulfide efflux and methanogenesis. Mar. Ecol. Prog. Ser. 382, 1-21.

Van der Wielen, P.J.J., Bolhuis, H., Daffonchio, D., Corselli, C., Giuliano, L., D'Auria, G., De Lange, G.J., Huebner, A., Varnavas, S.P., Thomson, J., Tamburin, C., Marty, D., McGenity, T.J., Timmis, K.N., Party, B.S., 2005. The Enigma of Prokaryotic Life in Deep Hypersaline Anoxic Basins. Science 307, 121-123. Wankel, S.D., Adams, M.M., Johnston, D.T., Hansel, C.M., Joye, S.B., Girguis, P.R., 2012. Anaerobic methane oxidation in metalliferous hydrothermal sediments: influence on carbon flux and decoupling from sulfate reduction. Environ. Microbiol. 14, 2726-2740.

Widdel, F., Bak, F., 1992. Gram-negative mesophilic sulfate-reducing bacteria, in: Balows, A., Trüper, H.G., Dworking, M., Harder, W., Schleifer, K.-H. (Eds.), The Prokaryotes. Springer, New York, pp. 33523378.

Windom, H.L., Schropp, S.J., Calder, F.D., Ryan, J.D., Smith, R.G., Burney, J.L.C., Lewis, F.G., Rawlinson, C.H., 1989. Natural trace metal concentrations in estuarine and coastal marine sediments of the Southeastern United States. Environ. Sci. Technol. 23, 314-320.

Yamamoto, S., Alcauskas, J.B., Crozier, T.E., 1976. Solubility of methane in distilled water and seawater. J. Chem. Eng. Data 21, 78-80.

Yoshinaga, M.Y., Holler, T., Goldhammer, T., Wegener, G., Pohlman, J.W., Brunner, B., Kyuypers, M.M.M., Hinrichs, K.-U., Elvert, M., 2014. Carbon isotope equilibration during sulphate-limited anaerobic oxidation of methane. Nature Geoscience 7, 190-194.

Zehnder, A.J.B., Brock, T.D., 1979. Methane formation and methane oxidation by methanogenic bacteria. J. Bacteriol. 137, 420-432.

Zehnder, A.J.B., Brock, T.D., 1980. Anaerobic methane oxidation: occurrence and ecology. Appl. Environ. Microbiol. 39, 194-204. 


\section{Figure Captions}

Figure 1. Ex situ (bio)geochemical profiles in the sediment core of PC13. Sulfate (zoomed out and zoomed in), sulfide, dissolved inorganic carbon (DIC), total alkalinity (TA), and trace metal concentrations are given per volume porewater. Methane concentration, and rates of sulfate reduction (SR) and anaerobic oxidation of methane (AOM) are given per volume sediment. R1 and R2 are replicates. Carbon $\delta^{13} \mathrm{C}$ values are normalized against the Vienna Pee Dee Belemnite (VPDB) standard.

Figure 2. Ex situ (bio)geochemical profiles in the sediment core of PC12. Sulfate (zoomed out and zoomed in), sulfide, dissolved inorganic carbon (DIC), total alkalinity (TA), trace metal concentrations are given per volume porewater. Methane concentration, and rates of sulfate reduction (SR) and anaerobic oxidation of methane (AOM) are given per volume sediment. R1 and R2 are replicates. Carbon $\delta^{13} \mathrm{C}$ values are normalized against the Vienna Pee Dee Belemnite (VPDB) standard.

Figure 3. Depth profiles of the relative abundance of bacterial classes and named environmental groups (Ribosomal Database Project Level 4) in PC13 estimated from multi-tag pyrosequencing of $16 S$ rRNA genes.

Figure 4. Depth profiles of the relative abundance of Deltaproteobacteria orders (Ribosomal Database Project Level 5) in PC13 estimated from multi-tag pyrosequencing of 16S rRNA genes.

Figure 5. Depth profiles of the relative abundance of archaeal classes and named environmental groups (Ribosomal Database Project Level 4) in PC13 estimated from multi-tag pyrosequencing of $16 S$ rRNA genes.

Figure 6. In-vitro methane production (ppmv in the headspace) at in-situ temperature $\left(0.5^{\circ} \mathrm{C}\right.$ ) of sediment slurries from different depths below the sulfate-methane transition zone of PC13 and PC12. Error bars represent standard deviation of three replicates.

Figure 7. In vitro inhibition experiments with 2-bromoethanesulfonate (BES; inhibitor for methanogenesis and anaerobic oxidation of methane (AOM)) and molybdate (Mb; inhibitor for sulfate reduction (SR)) with sediment slurries from different depths below the sulfate-methane transition zone of PC13 and PC12. AOM was investigated in methane-saturated slurries; organoclastic sulfate reduction was investigated in methane-free slurries. Rates of AOM and sulfate reduction were determined with radiotracers and are given per volume undiluted sediment. Error 
bars represent standard deviation of three replicates. $\mathrm{w} B E S, \mathrm{w} \mathrm{Mb}=$ inhibitor added; w/o BES, w/o $\mathrm{Mb}=$ without inhibitor; dashed line = separator for PC13 and PC12 samples.

Figure 8. Network of potential reactions with barite, manganese, and iron supporting sulfate reduction activity below the sulfate-methane transition zone. The electron donor is delivered in the form of either organic matter $\mathrm{C}_{\text {org }}$ or $\mathrm{CH}_{4}$ (large input arrow). Arrows are pointing at reaction products, which are formed from the respective substrates (base of arrow). Dashed lines indicate alternative products (Eq. 11) or intermediate steps $\left(\mathrm{SO}_{4}{ }^{2-}\right.$ reduction and pyritization). For more details see discussion and equations in the text.

Figure S1. Correlation networks for microbial and abiotic interactions in PC13 at Ribosomal Database Project Level 6. Positive interactions $(r \geq 0.4)$ are indicated by green edge connectors. Negative interactions $(r \leq-0.4)$ are indicated by purple edge connectors. The networks display $(A)$ only positive interactions, $(B)$ only negative interactions, and $(C)$ all significant Spearman correlations $(P<0.05)$ between microbial and abiotic parameters and abiotic-abiotic interactions for all taxa (positive and negative). Positive and negative interactions depicted in A and B are provided separately for easier viewing.

Figure S2. Correlation networks for Deltaproteobacteria and abiotic interactions in PC13 at Ribosomal Database Project Level 6. Positive interactions $(r \geq 0.4)$ are indicated by green edge connectors. Negative interactions $(r \leq-0.4)$ are indicated by purple edge connectors. The networks display (A) only positive interactions, (B) only negative interactions, and (C) all significant Spearman correlations $(P<0.05)$ between Deltaproteobacteria and abiotic parameters and abiotic-abiotic interactions (positive and negative). Positive and negative interactions depicted in (A) and (B) are provided separately for easier viewing.

Figure S3. In vitro experiments with methane-saturated sediment slurries from different depths below the sulfate-methane transition zone of PC13 and PC12, testing the effect of iron (Fe) and manganese $(\mathrm{Mn})$ addition on either anaerobic oxidation of methane (AOM) or sulfate reduction (SR). Background represents controls (original sediment slurry) without Fe or Mn additions. White bars = no inhibitor added; black bars = BES added; dashed bars = molybdate added (compare Fig 7). Rates are given per volume undiluted sediment. Error bars represent standard deviation of three replicates. 
Table 1. Overview of inhibition experiments with molybdate $(\mathrm{Mb})$ and 2-

bromoethanesulfonic acid (BES) for the investigation of sulfate reduction (SR) and anaerobic oxidation of methane (AOM) in sediments slurries from PC 13 and PC 12. Each experimental setup was prepared in triplicates. $\mathrm{N}_{2}$ and $\mathrm{CH}_{4}$ denote preparation under nitrogen or methane atmosphere, respectively. ${ }^{35} \mathrm{~S}$ and ${ }^{14} \mathrm{C}$ are radiotracers added.

\begin{tabular}{|c|c|c|c|c|c|c|}
\hline \multirow[b]{2}{*}{ Treatment } & \multicolumn{6}{|c|}{ Additions } \\
\hline & $\mathbf{N}_{2}$ & $\mathrm{CH}_{4}$ & $\begin{array}{c}\mathrm{Mb} \\
(22 \mathrm{mM})\end{array}$ & $\begin{array}{c}\text { BES } \\
(60 \mathrm{mM})\end{array}$ & ${ }^{35} \mathrm{~S}^{-\mathrm{SO}_{4}}{ }^{2-}$ & ${ }^{14} \mathrm{C}-\mathrm{CH}_{4}$ \\
\hline SR w Mb & $\bar{x}$ & & $\bar{x}$ & & $x$ & \\
\hline $\mathrm{SR} w / o \mathrm{Mb}$ & $x$ & & & & $x$ & \\
\hline AOM w Mb & & $x$ & $x$ & & & $x$ \\
\hline AOM w/o Mb & & $x$ & & & & $x$ \\
\hline SR w BES & $x$ & & & $x$ & $x$ & \\
\hline SR w/o BES & $x$ & & & & $x$ & \\
\hline AOM w BES & & $x$ & & $x$ & & $x$ \\
\hline AOM w/o BES & & $x$ & & & & $x$ \\
\hline
\end{tabular}


Table 2. Overview of manganese ( $\mathrm{Mn})$ and iron (Fe) treatments for the investigation of anaerobic oxidation of methane (AOM) and sulfate reduction in sediments slurries from PC 13 and PC 12. Each treatment was prepared under methane atmosphere. The entire suite of treatments was prepared twice for each depth, to allow separate incubations with ${ }^{14} \mathrm{C}-\mathrm{CH}_{4}$ and ${ }^{35} \mathrm{~S}_{-} \mathrm{SO}_{4}{ }^{2-}$.

\begin{tabular}{llc} 
Treatment & Addition & Replicates \\
\hline \hline Background controls & - & 3 \\
& + BES & 3 \\
Mn added & + Molybdate & 3 \\
& - & 3 \\
\multirow{3}{*}{ Fe added } & + BES & 3 \\
& + Molybdate & 3 \\
Medium controls & - & 3 \\
& + BES & 3 \\
& + Molybdate & 3 \\
& - & 5 \\
& + BES & 5 \\
\hline
\end{tabular}


Table 3. Reactions considered for the mass balance.

Reaction

Stoichiometry $^{\text {a }}$

Iron reduction using sulfide

$8 \cdot \mathrm{Fe}(\mathrm{OH})_{3}+\mathrm{H}_{2} \mathrm{~S}+14 \cdot \mathrm{H}^{+} \rightarrow 8 \cdot \mathrm{Fe}^{2+}+\mathrm{SO}_{4}{ }^{2-}+20 \cdot \mathrm{H}_{2} \mathrm{O}$

Iron reduction using methane

$8 \cdot \mathrm{Fe}(\mathrm{OH})_{3}+\mathrm{CH}_{4}+15 \cdot \mathrm{H}^{+} \rightarrow 8 \cdot \mathrm{Fe}^{2+}+\mathrm{HCO}_{3}{ }^{-}+21 \cdot \mathrm{H}_{2} \mathrm{O}$

Anaerobic oxidation of methane

$\mathrm{CH}_{4}+\mathrm{SO}_{4}{ }^{2-} \rightarrow \mathrm{HCO}_{3}^{-}+\mathrm{HS}^{-}+\mathrm{H}_{2} \mathrm{O}$

Sulfate reduction

$\mathrm{C}_{\text {org }}+1 / r_{\mathrm{C}: \mathrm{S}} \cdot \mathrm{SO}_{4}{ }^{2-} \rightarrow \mathrm{HCO}_{3}{ }^{-}+1 / r_{\mathrm{C}: \mathrm{S}} \cdot \mathrm{H}_{2} \mathrm{~S}$

Methanogenesis

$\mathrm{C}_{\text {org }} \rightarrow(4+o x) / 8 \cdot \mathrm{CO}_{2}+(4-o x) / 8 \cdot \mathrm{CH}_{4}$

${ }^{a} r_{C: S}$ and $o x$ are defined in the text. For clarity, water and protons are omitted from sulfate reduction and methanogenesis. 
Table 4. Input parameters for mass balance calculations and the derived fluxes. ${ }^{a}$

Parameters/fluxes

Temperature ( $T$ )

Burial velocity $(\omega)$

Depth of SMTZ

Porosity at the SMTZ $(\varphi)$

Dry sediment density $(\rho)$

Bulk sediment accumulation rate $\left(F_{\text {sed }}\right)$

Diffusion coefficient for $\mathrm{SO}_{4}{ }^{2-}$ in seawater $\left(D_{S W}\right)$

Diffusion coefficient for DIC in seawater $\left(D_{S W}\right)^{\mathrm{b}}$

Diffusion coefficient for $\mathrm{Fe}^{2+}$ in seawater $\left(D_{s w}\right)^{\mathrm{c}}$

Diffusion coefficient for $\mathrm{H}_{2} \mathrm{~S}$ in seawater $\left(D_{S W}\right)$

Diffusion coefficient for $\mathrm{CH}_{4}$ in seawater $\left(D_{S W}\right)$

Diffusion coefficient for $\mathrm{Ba}^{2+}$ in seawater $\left(D_{S w}\right)$

Diffusion coefficient for $\mathrm{Ca}^{2+}$ in seawater $\left(D_{s w}\right)$

Moles DIC produced per mole $\mathrm{SO}_{4}{ }^{2-}$ reduced $\left(r_{c: s}\right)$

Oxidation state of organic carbon (ox)

$\mathrm{SO}_{4}{ }^{2-}$ diffusive flux above $\mathrm{SMTZ}$

$\mathrm{SO}_{4}{ }^{2-}$ diffusive flux below SMTZ

DIC diffusive below SMTZ

DIC diffusive flux above SMTZ

$\mathrm{Fe}^{2+}$ diffusive flux below SMTZ

$\mathrm{H}_{2} \mathrm{~S}$ diffusive flux below SMTZ

$\mathrm{CH}_{4}$ diffusive flux below SMTZ

$\mathrm{Ba}^{2+}$ diffusive flux below SMTZ

$\mathrm{Ca}^{2+}$ diffusive flux below SMTZ

$\Sigma S R$ from SMTZ to bottom of the core

¿AOM from SMTZ to bottom of the core
PC13

0.5

0.283

105

$0.66 \quad 0.67$

2.5

0.24

151

157

102

303

250

250

125

111

1.46

$-1.49$

0.016

0

$-0.0079$

$-0.021$

undefined

undefined

$-0.015$

undefined

undefined

0.18

0.19

${ }^{a}$ Postive diffusive fluxes are downward (into sediment)

${ }^{\mathrm{b}}$ Diffusion coefficient for DIC assumed to be equal to that for $\mathrm{HCO}_{3}{ }^{-}$

${ }^{c}$ Weighted average of $\mathrm{HS}^{-}$and $\mathrm{H}_{2} \mathrm{~S}$ assuming a 70:30 partitioning (respectively) for a $\mathrm{pH}$ of 7.5
PC12 Unit

$0.5 \quad{ }^{\circ} \mathrm{C}$

$0.283 \mathrm{~cm} \mathrm{yr}^{-1}$

$\mathrm{cm}$

$67 \mathrm{~cm}^{3}$ porewater $\left(\mathrm{cm}^{3} \text { wet sed. }\right)^{-1}$

$2.5 \mathrm{~g} \mathrm{~cm}^{-3}$

$0.23 \mathrm{~g} \mathrm{~cm}^{-2} \mathrm{yr}^{-1}$

$151 \mathrm{~cm}^{2} \mathrm{yr}^{-1}$

$157 \mathrm{~cm}^{2} \mathrm{yr}^{-1}$

$102 \mathrm{~cm}^{2} \mathrm{yr}^{-1}$

$303 \mathrm{~cm}^{2} \mathrm{yr}^{-1}$

$250 \quad \mathrm{~cm}^{2} \mathrm{yr}^{-1}$

$125 \mathrm{~cm}^{2} \mathrm{yr}^{-1}$

$111 \mathrm{~cm}^{2} \mathrm{yr}^{-1}$

$1.66-$

$-0.82-$

$0.014 \quad \mathrm{mmol} \mathrm{cm}^{-2} \mathrm{yr}^{-1}$

$7.0 \times 10^{-4} \quad \mathrm{mmol} \mathrm{cm}^{-2} \mathrm{yr}^{-1}$

$-0.0065 \quad \mathrm{mmol} \mathrm{cm}^{-2} \mathrm{yr}^{-1}$

$-0.021 \quad \mathrm{mmol} \mathrm{cm}^{-2} \mathrm{yr}^{-1}$

$-8.9 \times 10^{-6} \quad \mathrm{mmol} \mathrm{cm}^{-2} \mathrm{yr}^{-1}$

$-6.6 \times 10^{-6} \quad \mathrm{mmol} \mathrm{cm}{ }^{-2} \mathrm{yr}^{-1}$

$-0.0089 \quad \mathrm{mmol} \mathrm{cm}^{-2} \mathrm{yr}^{-1}$

$-7.8 \times 10^{-6} \quad \mathrm{mmol} \mathrm{cm}^{-2} \mathrm{yr}^{-1}$

$0.0016 \quad \mathrm{mmol} \mathrm{cm}^{-2} \mathrm{yr}^{-1}$

$0.64 \quad \mathrm{mmol} \mathrm{cm}^{-2} \mathrm{yr}^{-1}$

$0.45 \quad \mathrm{mmol} \mathrm{cm}^{-2} \mathrm{yr}^{-1}$ 
Figure 1
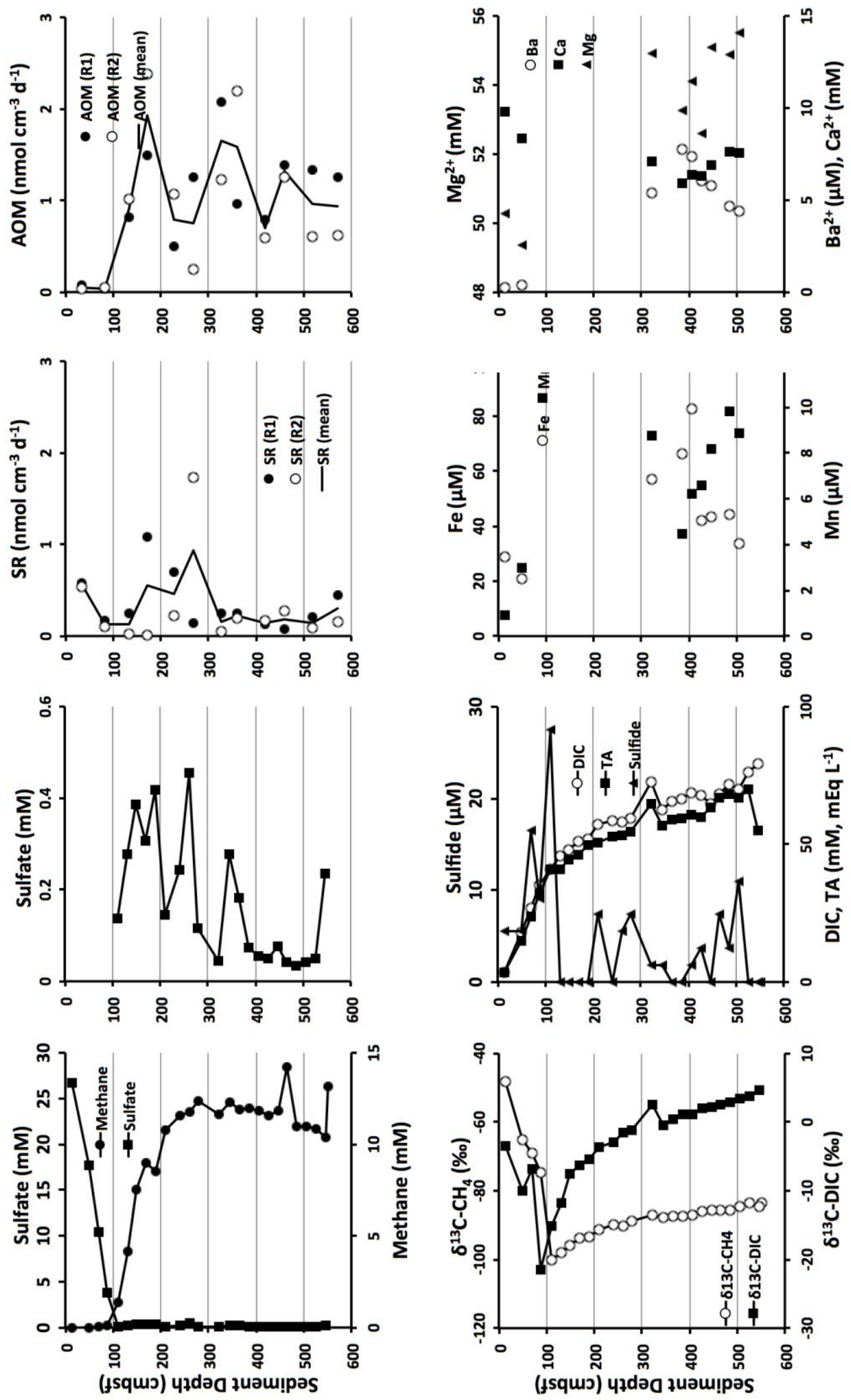
Figure 2
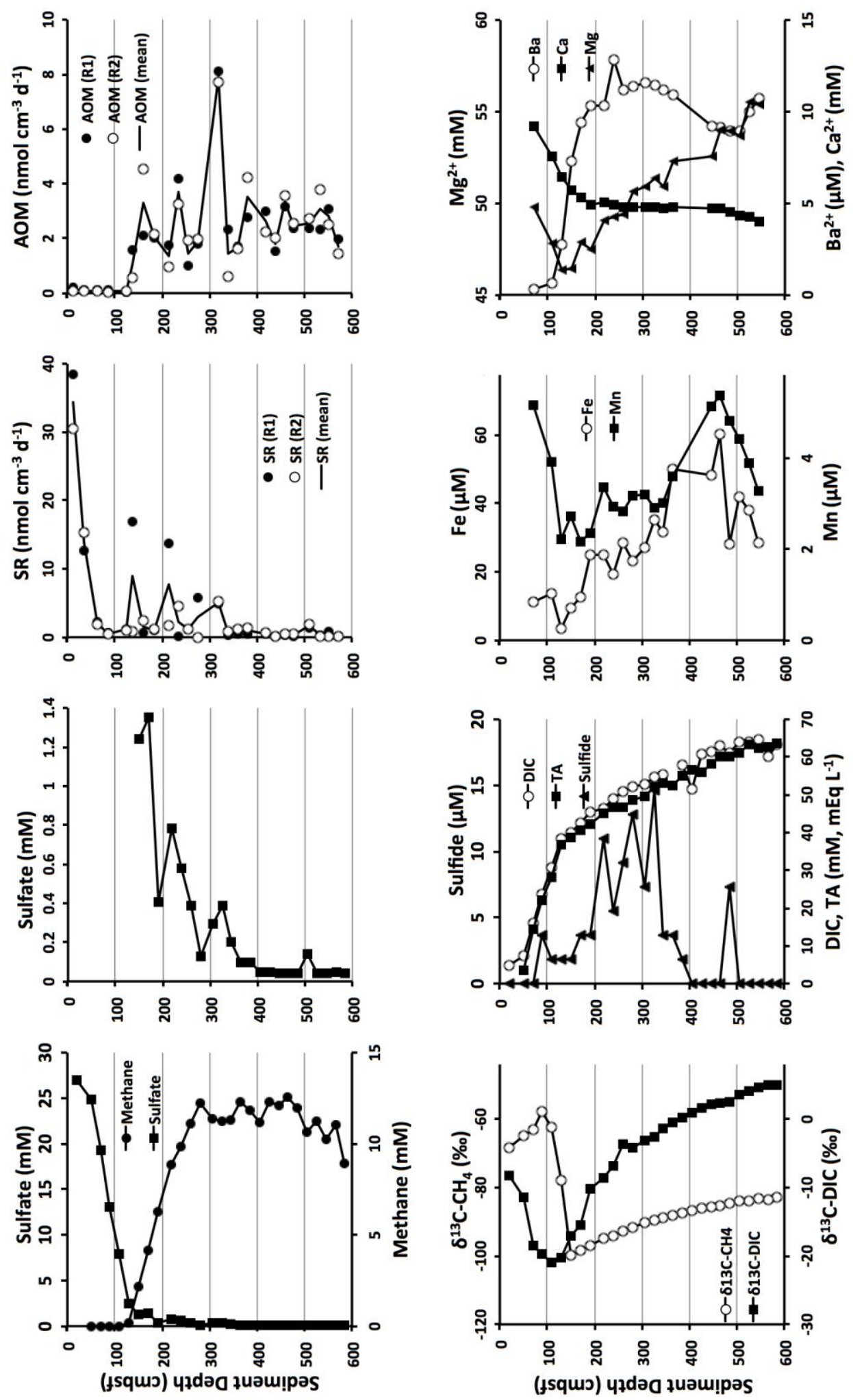
Figure 3

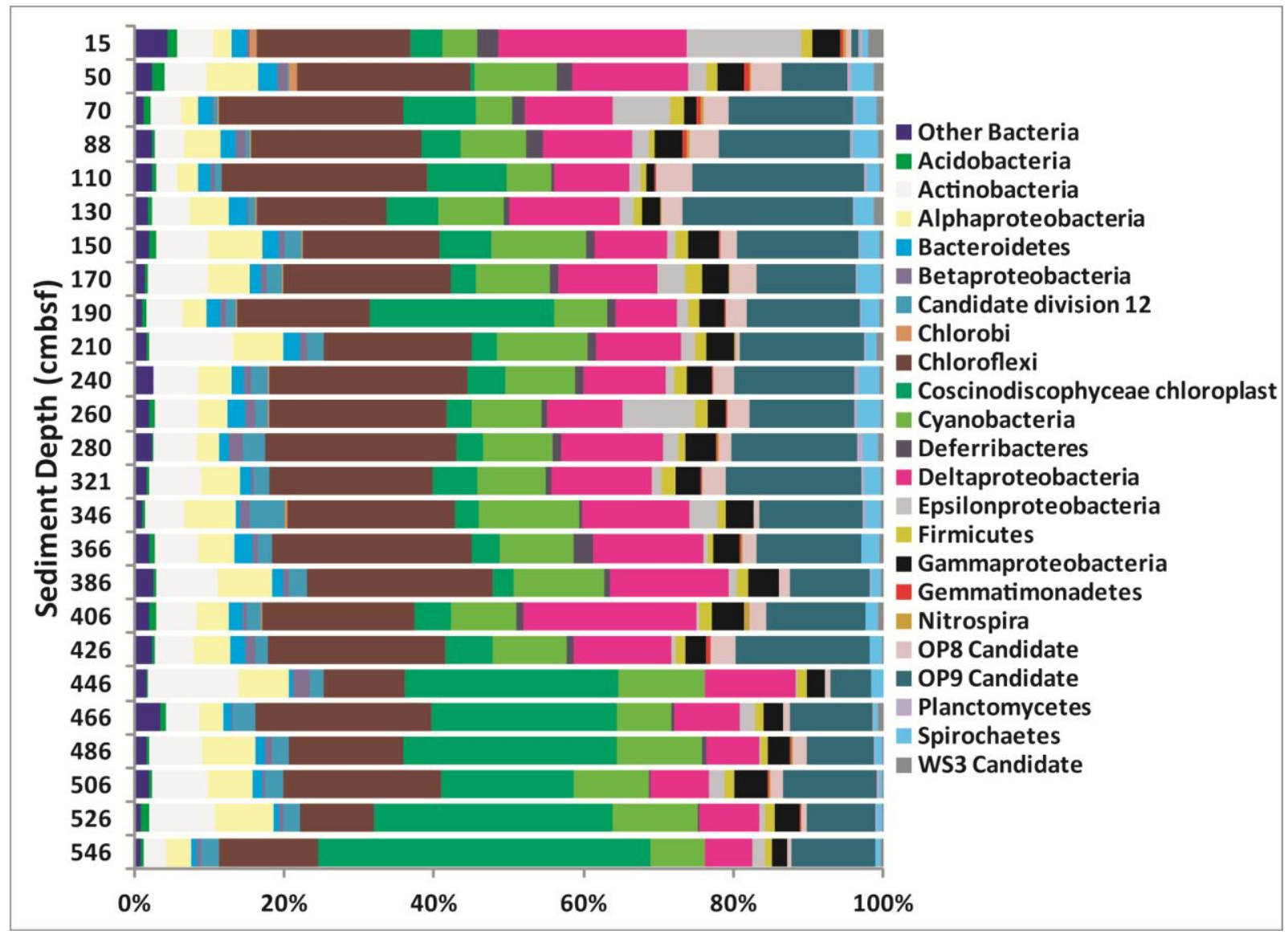


Figure 4

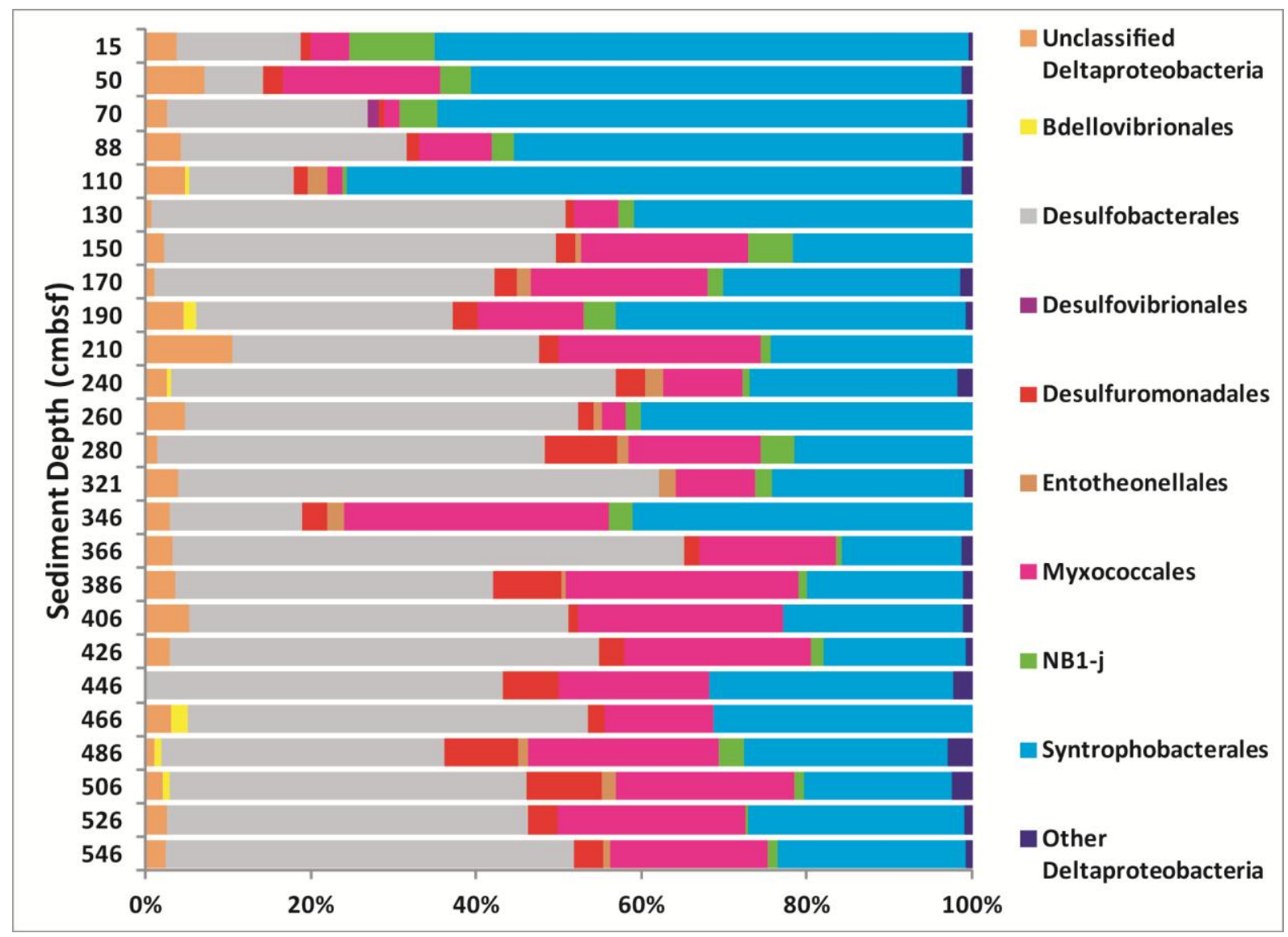


Figure 5

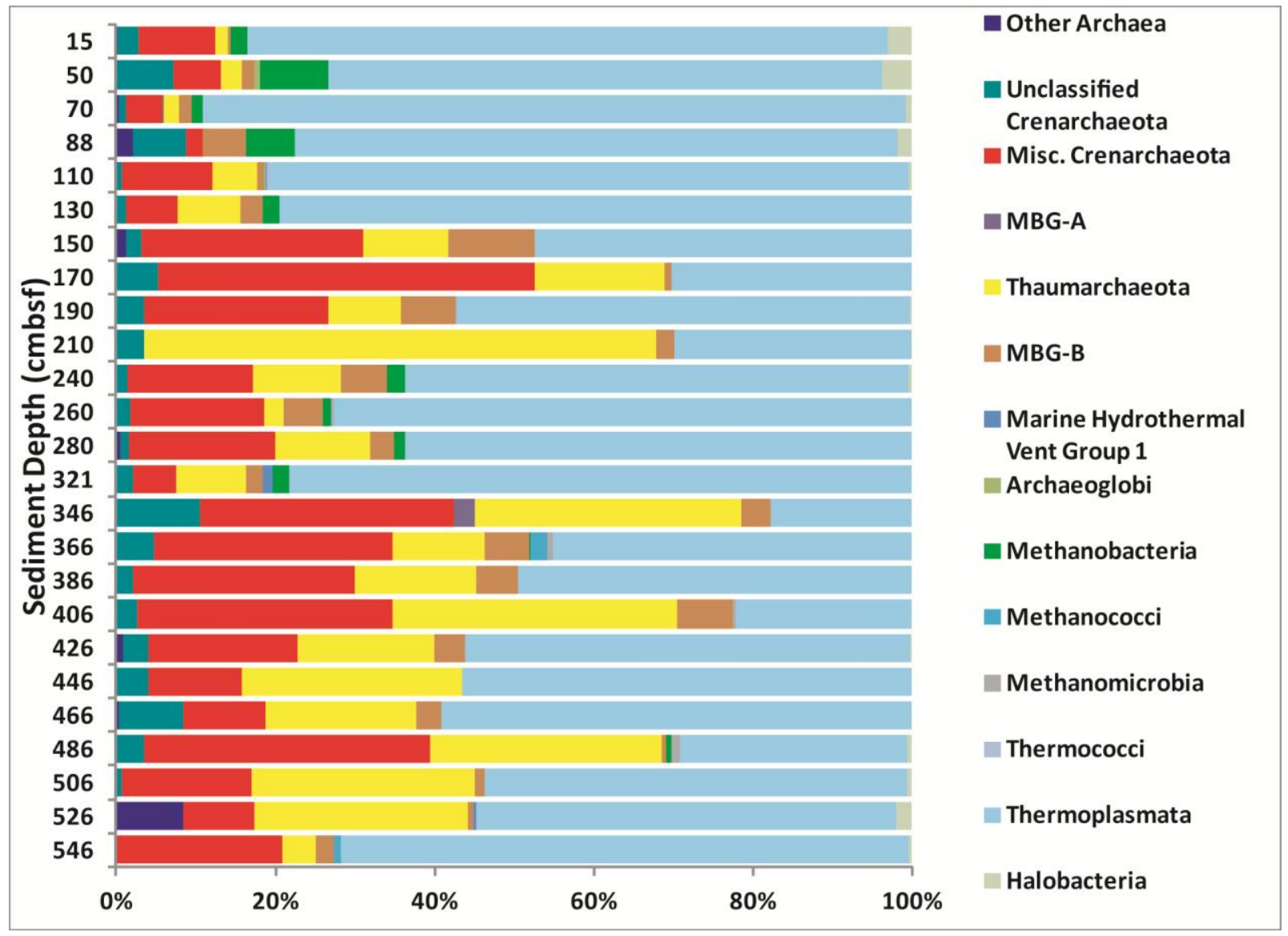


Figure 6
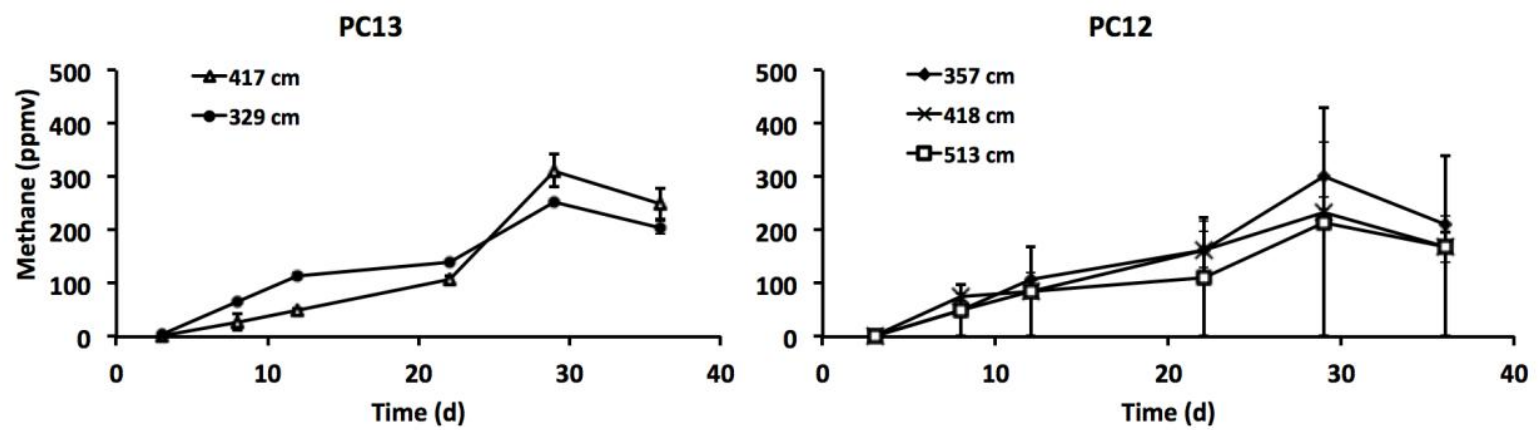
Figure 7
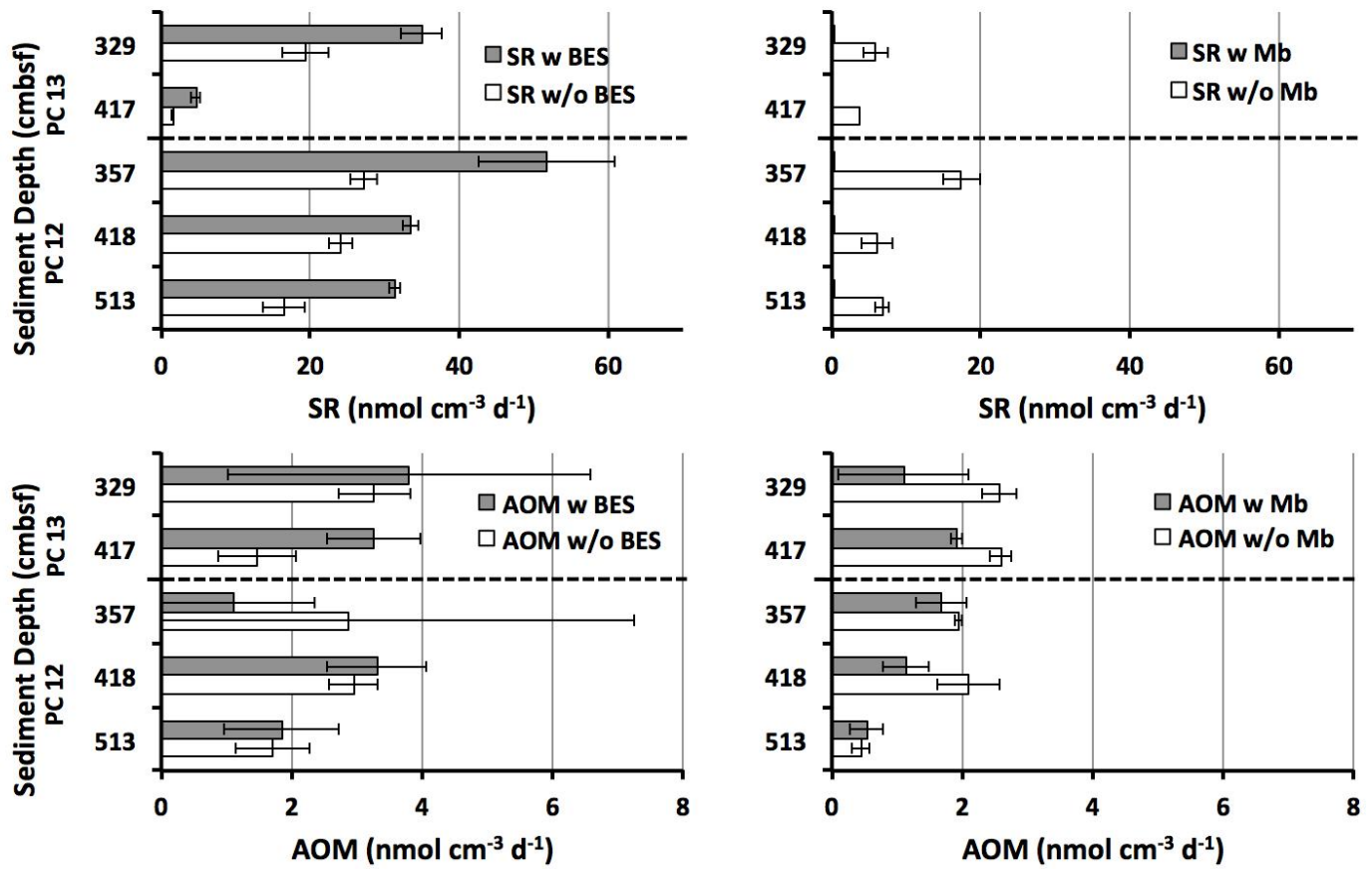
Figure 8

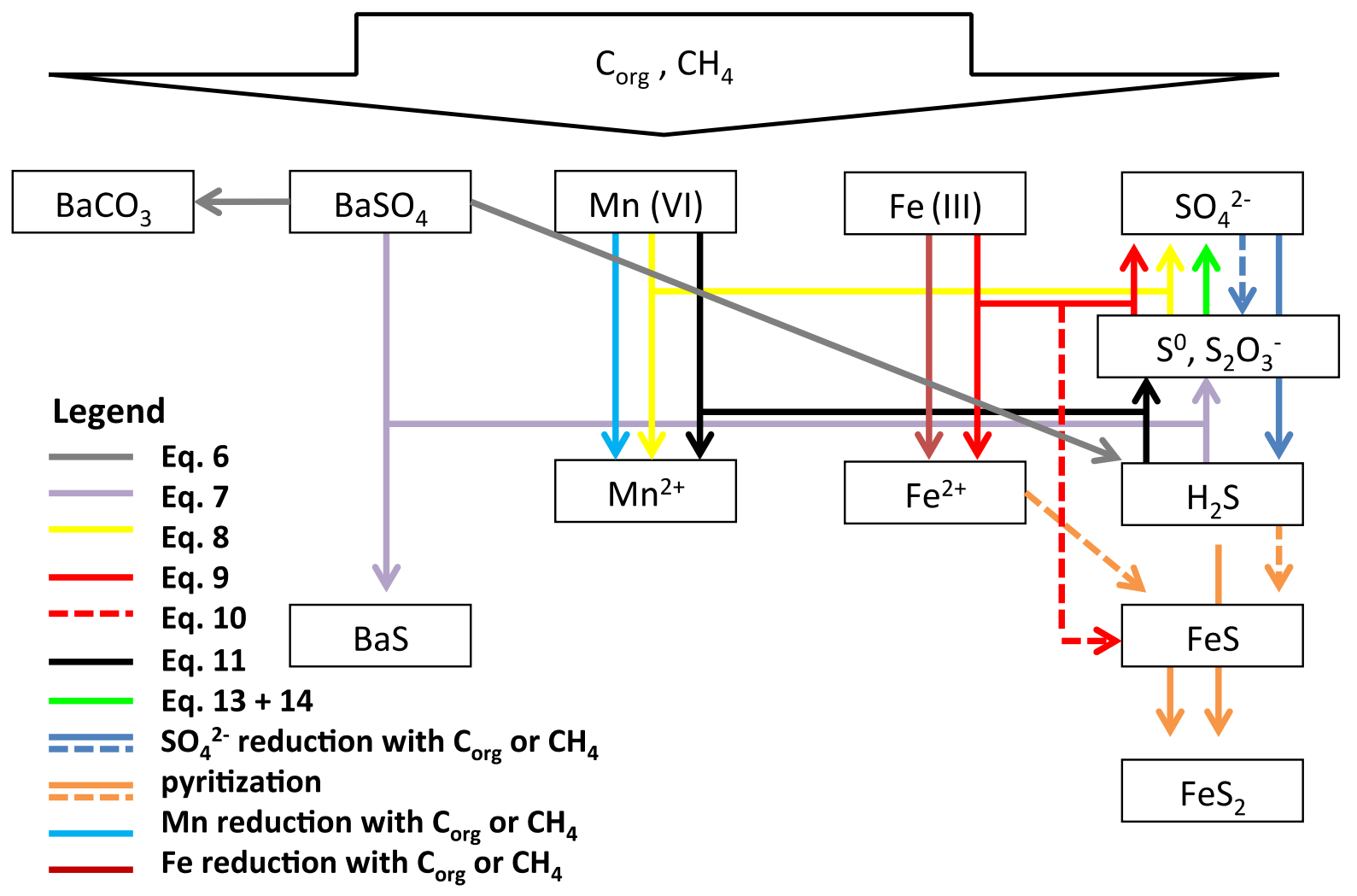

